\title{
El crédito a partir de los recursos de las cofradías en la provincia de Pamplona, siglo XVIII ${ }^{1}$
}

\begin{abstract}
Resumen
El crédito se constituyó en una variable fundamental para analizar el desarrollo económico de las colonias americanas. Aunque tradicionalmente se han estudiado los conventos y las capellanías como las instituciones religiosas a través de las cuales se posibilitó que se irrigaran recursos financieros a todo el sistema económico. En este artículo se examina detenidamente el caso de las obras pías y en particular el papel que desempeñaron las cofradías como fuente de crédito en un caso concreto: la provincia de Pamplona durante el siglo XVIII.
\end{abstract}

Palabras clave: Colombia, Pamplona, crédito, cofradías, historia colonial.

Referencia para citar este artículo: GUERRERO RINCÓN, Amado Antonio (2016). "El crédito a partir de los recursos de las cofradías en la provincia de Pamplona, siglo XVIII". En Anuario de Historia Regional y de las Fronteras. 21 (2). pp. 219-248.

Amado Antonio Guerrero Rincón: Doctor en Historia. Economista en Historia. Director del Grupo de Investigación sobre Desarrollo Regional y Ordenamiento Territorial. Miembro de la Asociación Colombiana de Historiadores. Profesor titular de la Escuela de Economía, Universidad Industrial de Santander. Correo electrónico: santiamen47@hotmail.com.

\footnotetext{
${ }^{1}$ El artículo se deriva del conjunto de reflexiones de la investigación que se realizó en el marco de la realización de la tesis doctoral intitulada Territorio, Economía y Sociedad. Desarrollo Regional en la provincia de Pamplona, siglo XVIII, (tesis doctoral), Huelva, Universidad Internacional de Andalucía, 2014.
} 


\title{
Brotherhoods and Loans in the Province of Pamplona, in the $18^{\text {th }}$ Century
}

\begin{abstract}
Loans became a fundamental variable to analyze the economic development of the colonies of the Americas. Although chaplaincies have traditionally been studied as the religious institution through which it was possible to supply financial resources throughout the economic system; this article studies the case of pious works, in particular the role played by brotherhoods as a source of loans, specifically, the province of Pamplona during the $18^{\text {th }}$ century.
\end{abstract}

Keywords: Colombia, Pamplona, Loans, Brotherhoods, Colonial History.

\section{As confrarias e o crédito na província de Pamplona, século XVIII}

\section{Resumo}

O crédito constituiu uma variável fundamental para analisar o desenvolvimento econômico das colonias americanas. Ainda que tradicionalmente foram estudadas as capelanias como a instituição religiosa através das quais foi possível que chegassem recursos financeiros a todo o sistema econômico, neste artigo é examinado detalhadamente o caso das obras religiosas e em particular o papel que desempenharam as confrarias como fonte de crédito em um caso concreto, a província de Pamplona durante o século XVIII.

Palavras chave: Colombia, Pamplona, Crédito, Confraria, História Colonial. 


\section{Introducción}

En un artículo reciente, la investigadora María del Pilar Martínez López-Cano ha señalado la estrecha articulación y dependencia de las actividades económicas coloniales de algún tipo de crédito o de financiamiento, pues el desarrollo de la agricultura, la ganadería, la minería, el comercio, el transporte, el sector artesanal y los obrajes, la comercialización de la producción, la provisión y retención de parte de mano de obra; requerían de inversiones y de capitales que, en muchos casos, se obtuvieron a crédito; y agrega además, cómo “[...] el crédito se utilizó ampliamente para afrontar necesidades relacionadas con el consumo, así como gastos extraordinarios derivados de una enfermedad, de un revés en los negocios, de la construcción y reparación de la vivienda, de una dote ante el matrimonio o la entrada en la vida religiosa de un miembro de la familia, y hasta para fines espirituales como la dotación de memorias de misas, de capellanías o fundaciones piadosas"2, sin descontar la solicitud de préstamos por parte de la Corona para afrontar sus necesidades financieras ${ }^{3}$. Es obvio que a lo largo del periodo colonial, en la medida en que se diversificaba la estructura productiva con los recurrentes ciclos de auge y estancamiento de cierto tipo de actividades, especialmente las relacionadas con el sector minero, la configuración y la consolidación de centros y economías urbanas, la ampliación de la frontera agraria con la incorporación de regiones agroexportadoras a los circuitos del comercio internacional, y el establecimiento de un amplio espectro de relaciones sociales y culturales cada vez más complejas, se hacía cada vez más necesario el acceder a recursos de capital para financiar las diferentes actividades económicas y con ello se registró la expansión y la generalización de los mecanismos de crédito para obtener dichos recursos que en términos generales provenían de tres fuentes esencialmente: el comercio -crédito comercial-, la Real Hacienda -crédito público- y la Iglesia crédito eclesiástico-, ante la ausencia de instituciones crediticias propiamente dichas.

Dada la importancia que adquirió el crédito eclesiástico en el desenvolvimiento de la vida económica y social, este es uno de los ejes temáticos que más ha llamado la atención en la historia económica colonial de ciertas regiones como México y Perú y sobre dichas regiones existe una abundante bibliografía ${ }^{4}$. Sin embargo, a pesar de su importancia, este ha sido una temática poco explorada en forma explícita en las

\footnotetext{
${ }^{2}$ Martínez López-Cano, María del Pilar. "La Iglesia y el crédito en Nueva España: entre viejos presupuestos y nuevos retos de investigación”, en Martínez López-Cano, María de Pilar (coord.), La Iglesia en Nueva España. Problemas y perspectivas de investigación (México: Universidad Nacional Autónoma de México, Instituto de Investigaciones Históricas, 2010), p. 303.

${ }^{3}$ Ibid.

${ }^{4}$ Bauer, Arnold J. La iglesia en la economía de América Latina (México: Instituto Nacional de Antropología e Historia, 1986); Martínez López-Cano, Pilar (comp.). Iglesia, estado y economía. Siglos XVI al XIX (México: UNAM, Instituto de Investigaciones Dr. José María Luis Mora, 1995); Von Wobeser, Gisela. Vida eterna y preocupaciones terrenales. Las capellanias de misas en la Nueva. España, 1600-1821 (México: UNAM, 2005); Chamoux, Marie-Nöelle, et al., (coords.). Prestar y pedir prestado. Relaciones sociales y crédito en México del siglo XVI al XIX (México: Secretaría de Educación Pública/Centro de Investigaciones y Estudios Superiores en Antropología Social, 1993); Von Wobeser, Gisela. El crédito eclesiástico en la Nueva España. Siglo XVIII (México: Universidad Nacional Autónoma de México, Coordinación de Humanidades e Instituto de Investigaciones Históricas, 1994).
} 
investigaciones históricas sobre el periodo colonial del Nuevo Reino de Granada, pues más allá de los trabajos pioneros de Germán Colmenares ${ }^{5}$, están los trabajos de Juan Manuel Robayo Avendaño ${ }^{6}$, Carmen Adriana Ferreira Esparza ${ }^{7}$ y Juan Sebastián Marulanda Restrepo ${ }^{8}$, y aunque el tema es abordado parcialmente en las investigaciones generales de historia económica sobre el periodo y en trabajos relacionados con instituciones religiosas específicas como los conventos, lo cierto es que el tratamiento sistemático con información estadística solo ha sido abordado para algunas décadas y regiones, como en el caso de Antioquia durante el periodo $1670-1750,1700-1790$, en Cali en los quinquenios $1725-1729$, 1735-1739 y 1747 1751; en Pamplona 1700-1760 y en Tunja en sus articulaciones y vinculaciones con la propiedad territorial para el siglo XVIII.

Si este es el panorama general del crédito, el estudio de las cofradías, una de las instituciones que hacían parte del crédito eclesiástico, es aún más incipiente, sobre todo si hace referencia a las interacciones que se establecían entre los aspectos religiosos y el desenvolvimiento económico de estas instituciones en el Nuevo Reino de Granada. De hecho, prácticamente el único estudio general que existe es el de Graff ${ }^{9}$, situación que no deja de llamar la atención ${ }^{10}$, dada la importancia que tuvieron las cofradías como la organización social más popular, con relativa autonomía en el manejo de sus asuntos y rentas, el ejercicio de prácticas de democracia corporativa en la elección de sus cuerpos de gobierno y de libre expresión en sus deliberaciones internas, el hecho de desarrollarse con fines asociativos y cooperativos para cumplir sus fines administrativos o piadosos, o actuar en la defensa de intereses comunitarios y como estrategia de cohesión social; es decir, ser portadora de una serie de valores que expresaban una mentalidad más moderna y que trascendía los fines escatológicos

\footnotetext{
5 Colmenares, Germán. "Censos y capellanías. Formas de crédito en una economía agrícola”, en Cuadernos Colombianos, núm. 2, Bogotá, 1974, pp. 123-144); y Cali: terratenientes, mineros y comerciantes, Siglo XVIII (Bogotá: Banco Popular, 1983).

${ }^{6}$ Robayo Avendaño, Juan Manuel. Iglesia, tierra y crédito en la Colonia. Tunja y su provincia en el siglo XVIII (Tunja: Universidad Pedagógica y Tecnológica de Colombia, 1995).

7 Ferreira Esparza, Carmen Adriana. La economía espiritual. Entre lo terrenal y lo celestial. Pamplona, siglo XVIII (Bucaramanga: CER-UIS-SIC, 2001); y "El crédito colonial en la provincia de PamplonaNueva Granada: usos del censo consignativo", en Signos Históricos, núm. 1, 1999, pp. 59-84.

${ }^{8}$ Marulanda Restrepo, Juan Sebastián. Comprando la eternidad a veinte mil el millar. El crédito religioso en la provincia de Antioquia, 1675-1750 (Medellín: Instituto para el desarrollo de Antioquia, 2013).

${ }^{9}$ Wendell Graff, Gary. Cofradias in the New Kingdom of Granada: lay fratiernities in a spanish american frontier saciety. 1600-1755, (tesis doctoral), Ann Arbor, University Microfilms international, 1983.

${ }^{10}$ En el caso del Nuevo Reino de Granada, sobre cofradías indígenas solo existe un trabajo de investigación con un enfoque global y una cobertura temporal extensa, que es el de Sotomayor, María Lucía. Cofradías, caciques y mayordomos. Reconstrucción social y reorganización politica en los pueblos de indios, siglo XVIII (Bogotá: Instituto Colombiano de Antropología e Historia, 2004). Aunque seguramente existen trabajos monográficos que aún no se han publicado y que abordan la estructura de funcionamiento de algunas cofradías durante ciertas coyunturas como el de González Acero, Juan Francisco. La cofradía de las Benditas Ánimas del Purgatorio en Fontibón 1683-1693 (Bogotá: Pontificia Universidad Javeriana, 2013).
} 
para acercarse a los intereses materiales más mundanos, tal y como se ha evidenciado en estudios realizados sobre otras regiones de la América colonial ${ }^{11}$.

En virtud de lo anterior y a partir del llamado que realiza María del Pilar Martínez López-Cano en su artículo "La Iglesia y el crédito en Nueva España: entre viejos presupuestos y nuevos retos de investigación", cuando señala que "[...] al estudiar la riqueza de la Iglesia y el crédito eclesiástico no podamos considerar a la Iglesia como una única institución, sino que tengamos que remitirnos a la riqueza y actividad crediticia de cada una de las corporaciones"12, en este artículo se aborda el estudio del

\footnotetext{
${ }^{11}$ Estos enfoques se encuentran en diferentes artículos y compilaciones, entre los cuales se pueden mencionar los siguientes: Martínez López-Cano, Pilar; Von Wobeser, Gisela y Muñoz, Juan Guillermo (coords.). Cofradias, capellanías y obras pías en la América Colonial (México: Universidad Nacional Autónoma de México, Instituto de Investigaciones históricas, 1998); Bazarte Martínez, Alicia. Las cofradías de españoles en la ciudad de México (1526-1869) (México: Universidad Autónoma Metropolitana-Azcapotzalco, 1989); Celestino, Olinda y Meyers, Albert. Cofradias en el Perú: Región central (Frankfurt: Vervuert, 1981); Egoavil, Teresa. Las Cofradias en Lima, siglos XVII y XVIII (Lima: Universidad Nacional Mayor San Marcos, 1986); Callahan, William J. "Las cofradías y hermandades de España y su papel social y religioso dentro de una sociedad de estamentos”, en Martínez López-Cano, Pilar; Von Wobeser, Gisela y Muñoz, Juan Guillermo (coords.), Cofradias, capellanias y obras pías en la América Colonial (México: Universidad Nacional Autónoma de México, Instituto de Investigaciones históricas, 1998, pp. 35-47; Celestino, Olinda y Meyers, Albert. "La dinámica socio-económica del patrimonio cofradial en el Perú colonial: Jauja en el siglo XVII", en Revista Española de Antropología Americana, vol. XI, 1981, pp. 183-206; García Ayluardo, Clara. "Sociedad, crédito y cofradía en la Nueva España a fines de la época colonial: el caso de Nuestra Señora de Aránzazu", en Historias, núm. 3, 1983, pp. 53-68; Lavrin, Asunción. "Mundos en contraste: cofradías rurales y urbanas en México a fines del siglo XVIII", en Bauer, Arnold. J. La iglesia en la economía de América Latina (México: Instituto Nacional de Antropología e Historia, 1986); Luque Alcaide, Elisa. La cofradía de Aranzazu de México (1681-1799) (Pamplona: Eunate, 1995); Martínez de Codes, Rosa María. "Cofradías y capellanías en el pensamiento ilustrado de la administración borbónica (1760-1808)”, en Martínez López-Cano, Pilar; Von Wobeser, Gisela y Muñoz, Juan Guillermo (coords.). Cofradias, capellanías y obras pías en la América Colonial (México: Universidad Nacional Autónoma de México, Instituto de Investigaciones históricas, 1998), pp. 17-33; Pérez-Rocha, Emma. "Mayordomías y cofradías del pueblo de Tacuba en el siglo XVIII", en Estudios de Historia Novohispana, vol. VI, México, Universidad Nacional Autónoma de México, Instituto de Investigaciones Históricas, 1978, pp. 119-131.

${ }^{12}$ La autora sostiene que "[...] el estudio del crédito eclesiástico se ha ido enriqueciendo con multitud de enfoques que han combinado las perspectivas de distintas disciplinas, desde la historia económica, social, cultural, de las mentalidades, de la historia institucional, ideológica, política, regional y de la antropología del consumo. Solo desde esta visión de conjunto es posible entender la importancia de la Iglesia en el crédito y, por extensión, en la economía colonial", y dentro de los nuevos retos para la investigación de esta temática, los enormes vacíos que aún quedan para diferentes épocas, obispados e instituciones, el estudio del crédito eclesiástico en conjunto con el proporcionado por otros actores para evaluar su peso y alcance a lo largo de tres siglos, para concluir señalando que "[...] Estudiar las relaciones y ligas entre instituciones acreedoras y deudores, la mentalidad religiosa que propició o privilegió la riqueza de unas fundaciones por encima de otras, las continuidades y cambios de las prácticas piadosas a lo largo de la época colonial, estudiar a las instituciones eclesiásticas más allá de los objetivos espirituales que se habían propuesto, y analizar el significado que tuvieron en las condiciones sociales, económicas y políticas en las que operaron, ayudaría a entender mejor no solo el crédito, sino la economía y la sociedad de la que formaron parte, a la vez que plantear nuevas problemáticas como la secularización o laicización y, en definitiva, el peso de la Iglesia en el ámbito colonial y dentro de la monarquía hispánica, y después de la independencia nacional”. Martínez López-Cano, María del Pilar. "La Iglesia y el crédito en Nueva España: entre viejos presupuestos y nuevos retos de investigación”, en Martínez López-Cano, María de Pilar (coord.). La Iglesia en Nueva España. Problemas y perspectivas de investigación (México: Universidad Nacional Autónoma de México, Instituto de Investigaciones Históricas, 2010), pp. 309 y 331.
} 
crédito que se realizó en la Provincia de Pamplona, durante el siglo XVIII, a partir de los recursos que manejaban las cofradías que funcionaban en esta jurisdicción. La selección del espacio geográfico y la temporalidad establecida, se justifica en la medida en que en dicho periodo, esta región realizó un proceso de transformación y especialización productiva, a partir del cultivo del cacao, y de vinculación y articulación a los mercados internacionales, especialmente con Nueva España, a través de la ruta comercial establecida por el lago de Maracaibo, siendo la primera región agroexportadora del Nuevo Reino de Granada que alcanzó un gran dinamismo y crecimiento durante el periodo ${ }^{13}$; y se privilegió el análisis de las cofradías, por encima de los Conventos ${ }^{14}$ y Capellanías -las otras dos fuentes principales del crédito eclesiástico-, porque a lo largo del siglo esta corporación tuvo un proceso de fortalecimiento en la región, que la llevó a constituirse en una de las principales fuentes de recursos de capital y poseedora de grandes propiedades como la hacienda de Agua Sucia, con más de 50.000 árboles de cacao, y la administración de la hacienda de Mataredonda, dedicada al cultivo de la caña que alcanzó a poseer más de 100 esclavos.

Este artículo se inscribe entonces en el contexto de las nuevas perspectivas analíticas que le otorgan un papel dinamizador al crédito eclesiástico en las economías regionales, máximo si estas son de carácter agropecuario que requería de créditos a largo plazo para su funcionamiento, y de particularizar el papel que jugaban las diferentes corporaciones que hacían parte de la Iglesia católica, abordando en específico los aspectos económicos, sin desconocer la importancia del rol que desempañaban como instituciones de carácter social y religioso.

\section{El contexto regional}

Durante la colonia, y específicamente el siglo XVIII, la provincia de Pamplona, al igual que las demás regiones del Nuevo Reino de Granada, no escapó al imaginario colectivo de sus habitantes, una región llevada por el orden institucional de la Iglesia y el tinte social de estatus y segregación racial, componentes del hilo conductor de la sociedad pamplonesa. La Iglesia, como ente rector de la moral y de los preceptos religiosos, señalaba a los laicos las normas y actos que eran agradables a los ojos de Dios, y que la sociedad temerosa de los mandatos divinos debía cumplir para lograr el beneficio máximo: la salvación de su alma. En este paso por la tierra se debían hacer las obras y los actos que permitieran alcanzar la gracia de Dios y que por ende abrir las puertas al paraíso.

\footnotetext{
${ }^{13}$ Guerrero Rincón, Amado Antonio. Territorio, Economía y Sociedad. Desarrollo Regional en la provincia de Pamplona, siglo XVIII, (tesis doctoral), Huelva, Universidad Internacional de Andalucía, 2014.

${ }^{14}$ Una de las investigadoras que más ha trabajado los aspectos relacionados con los conventos es: Lavrin, Asunción. "La riqueza de los conventos de monjas en Nueva España. Estructura y evolución durante el siglo XVIII", en Cahiers des Ameriques Latines, vol. VIII, 1973; "El capital eclesiástico y las élites en Nueva España", en Mexican Studies/Estudios Mexicanos, vol. I, núm. 1, México, 1985, pp. 1-28; "Los conventos de monjas en la Nueva España", en Bauer, Arnold J. La iglesia en la economía de América Latina siglos XVI al XIX (México: Instituto Nacional de Antropología e Historia, 1986).
} 
Al iniciarse la incursión en el Nuevo Mundo y su posterior colonización, la implantación del modelo cultural y social español fue uno de los principales objetivos de los colonizadores, comenzando por el establecimiento de la Iglesia como la entidad rectora de la moral y guiadora del pasto espiritual de los habitantes de los territorios conquistados. No es de extrañar entonces cómo recién fundada la ciudad de Pamplona y en el curso de los siguientes 40 años, se construyó el utillaje material que mejor expresaba el fervor religioso de sus habitantes. La construcción de la capilla de Las Nieves se inició en 1553, cuatro años después de fundada la ciudad, siendo este el primer sitio de culto, y en 1555 se inició la del templo parroquial que estaba más acorde con el estatus que se le quería dar a la ciudad y ostentar sus habitantes; en 1555 se inició la construcción de la casa de religiosos de Santo Domingo, que años más tarde se convirtió en el convento de Santo Domingo; en 1584 la del convento de Santa Clara; en 1590 la del convento de San Francisco -autorizado desde 1584- y el de San Agustín, y en 1621 la Compañía de Jesús abrió su casa y colegio, los cuales habían sido autorizados desde 1602; además, estaba el convento de San Juan de Dios que inició como hospital, administrado por el cabildo de la ciudad desde los primeros años de fundación de Pamplona ${ }^{15}$.

Las fundaciones de iglesias y conventos evidenciaban el deseo y la necesidad de los habitantes de la ciudad de Pamplona de tener representaciones a las cuales hacer sus peticiones espirituales y ganar indulgencias a través de la devoción y las donaciones que les hacían, para en un futuro darles tranquilidad a sus almas y ganar la gracia de Dios. Así entonces la Iglesia fue creando y reafirmando el imaginario religioso en la población de la provincia de Pamplona durante la Colonia. Comúnmente, la Iglesia planteaba que la forma de vida que se había llevado en la Tierra iba a ser, de cierta forma, un reflejo de lo que le esperaría al alma en el cielo. Llevar una vida contraria a los preceptos religiosos era declaración de una condenación del alma. El mayor miedo de la sociedad pamplonesa era que una vez llegado el momento de la muerte su alma quedara vagando en el Purgatorio, temor que explica la realización de actos benéficos y piadosos a favor de la Iglesia, ya que ellos, en conjunto ayudarían a las almas a llegar al lugar deseado, el Cielo, y lejos de su mayor preocupación: el Infierno ${ }^{16}$.

La evolución material de las diferentes construcciones religiosas hacía parte de la mentalidad de los habitantes de la región, quienes notaban que iban ganando espacio geográfico con la ampliación de sus límites jurisdiccionales y por tanto, dichas construcciones realzaban la importancia de la ciudad. Con el apoyo material de la sociedad pamplonesa, la organización de las doctrinas y la llegada de los primeros visitadores eclesiásticos se fueron estableciendo hasta lograr la construcción de toda una serie de iglesias y conventos, y con ellas instituciones como las capellanías, las

\footnotetext{
${ }^{15}$ Rico Villamizar, José. Pamplona o la historia del nororiente colombiano, t. II (Bogotá: Crea Arte, 1990), pp. 497-503.

${ }^{16} \mathrm{Al}$ respecto se puede consultar: Le Goff, Jacques. La bolsa y la vida. Economía y religión en la edad media (Barcelona: Gedisa, 1987); El nacimiento del Purgatorio (Madrid: Taurus, 1981); Álvarez Santalo, Carlos, et al. La religiosidad popular (Barcelona: Anthropos, 1989); Lomnitz, Claudio. La idea de la muerte en México (México: Fondo de Cultura Económica, 2006); Eliade, Mircea. Lo sagrado y lo profano (Barcelona: Labor, 1983).
} 
obras pías y las cofradías ${ }^{17}$. Aunque parte fundamental de los legados piadosos, la constituían las capellanías ${ }^{18}$ y las cofradías, la diferencia fundamental entre ambos era que las primeras estaban orientadas a la búsqueda de bienes espirituales como la salvación del alma, asegurar una renta a actuales o futuros curas o financiar la entrada y sostenimiento de monjas y novicias; las obras pías buscaban estimular otros valores $^{19}$, de carácter benéfico y piadoso asistencial, se hacían sobre imágenes de devoción, instituciones y memorias, pretendiendo favorecer las políticas por medio de las cuales tanto la Corona como la Iglesia brindaban auxilios a los miembros que pertenecían a una determinada cofradía, sostenían el culto o fiestas religiosas de santos patrones, socorrían a la sociedad marginada o los desposeídos por medio de los conventos de misericordia y los hospitales, o prestaban servicios de caridad con los huérfanos, desheredados y enfermos ${ }^{20}$. Este tipo de fundación, además, tenía como función contribuir con la edificación o reparación de los templos parroquiales, ayudar con los costes de funcionamiento de las parroquias al contribuir con los gastos de cera para alumbrar alguna imagen y el mantenimiento de la ermita donde eran colocadas las imágenes ${ }^{21}$. Las cofradías fueron entonces otra forma de administrar la fe, como asociaciones voluntarias de fieles laicos para venerar a un santo patrón, escogido para generar mayor devoción y piedad, y en nombre de este patrono se ejercían los actos de caridad, especialmente entre los propios miembros en forma de ayuda mutua.

\footnotetext{
17 “[...] las cofradías conferían a sus miembros el acceso a unos bienes espirituales determinados por las promesas de indulgencias papales y las actividades benéficas a que se comprometían, orientadas a la salvación del alma. Los beneficios materiales podían ser de diversa índole, haciéndose notorios los relativos a la ayuda en la enfermedad, pobreza y muerte. Además, pertenecer a ciertas cofradías cuyo ingreso era restringido, fue una muestra de estatus y poder económico y político". Ferreira Esparza, Carmen Adriana. La economía espiritual. Entre lo terrenal y lo celestial. Pamplona, siglo XVIII (Bucaramanga: CER-UIS-SIC, 2001), p. 35.

${ }^{18}$ La capellanía consistía en la dotación de una plaza vitalicia de cura (un capellán) que se vinculaba a una ermita o templo ya existente o a una capilla privada con la obligación de realizar cierto número de misas por el alma del fundador y, habitualmente, también por su familia. Para el mantenimiento de la capellanía y manutención del cura-capellán, el fundador destinaba una parte de su patrimonio que generara rentas, establecía el tipo de capellanía, las condiciones del disfrute, nombraba al patrono o administrador, designaba al beneficiario y establecía el proceso de sucesión cuando la capellanía quedara vacante; se podía decir que después de fundarse las capellanías se cedían por medio de traspaso o reconocimiento del censo. Von Wobeser, Gisela. El crédito eclesiástico en la Nueva España. Siglo XVIII (México: Universidad Nacional Autónoma de México, Coordinación de Humanidades e Instituto de Investigaciones Históricas, 1994).

${ }^{19}$ Para una exploración sobre los motivos que conducían a los feligreses a dejar sus bienes a la Iglesia, con el fin de contribuir a la salvación de sus almas, y cómo estos bienes se convirtieron en la base del sistema crediticio colonial, se pueden consultar a Von Wobeser, Gisela. Vida eterna y preocupaciones terrenales. Las capellanías de misas en la Nueva. España, 1600-1821 (México: UNAM, 2005).

${ }^{20}$ Lavrin, Asunción. "Cofradías novohispanas: economías material y espiritual”, en Martínez López-Cano, Pilar; Von Wobeser; Gisela y Muñoz, Juan Guillermo, (coords.). Cofradías, capellanías y obras pías en la América Colonial (México: UNAM, 1998).

${ }^{21}$ De hecho, en el proceso de constitución de parroquias, los vecinos contraían una serie de obligaciones relacionadas con la construcción de la iglesia y la casa cural, la dotación con los ornamentos correspondientes de la iglesia para el desarrollo del culto divino, asegurar la congrua del cura y la fundación y mantenimiento con carácter obligatorio de las cofradías del Santísimo Sacramento, la de las Benditas Ánimas del Purgatorio, la de la Virgen María, en cualquiera de sus advocaciones, y la del Santo Patrón, que servían para la administración y funcionamiento de la mayoría de los oficios y celebraciones religiosas del feligresado de la parroquia constituida.
} 
En desarrollo de este proceso, en la Pamplona del siglo XVIII se encontraron en funcionamiento 23 cofradías y obras pías adscritas a la iglesia parroquial o a las diferentes órdenes religiosas. Aunque las había de diverso orden, unas atendiendo a referentes étnicos, como las conformadas por españoles, indígenas ${ }^{22}$, negros y mulatos -las cofradías urbanas habían superado este carácter para el siglo XVIII-, y otras orientadas a intereses corporativos como las de los gremios; en el caso que ocupa a este análisis solo se encontraron cofradía con fines únicamente religiosos y de ayuda mutua, entre ellas una cofradía indígena, la de Nuestra Señora de las Angustias, liderada por el pueblo de indios de Labateca (Cuadro 1).

La fundación de una cofradía se iniciaba con el establecimiento de los estatutos, en los cuales se establecían los derechos y las obligaciones entre los miembros y la cofradía. Su gobierno se establecía a través de las Juntas de Cabildo que anualmente realizaban sus miembros y en las que se elegían a los encargados de la administración, compuesto básicamente por un rector encargado de dirigir la cofradía, cargo que recaía en el cura o en religiosos, un mayordomo o hermano mayor que tenía como función hacer cumplir los estatutos, y tres o más diputados que ayudaban a recoger limosnas para las ceremonias de los festejos religiosos, recolectar las mensualidades de los cofrades o auxiliarlos en el control administrativo de gastos e ingresos. También disponían de un arca de las tres llaves ${ }^{23}$ que debía ser utilizada como archivo y caja de tesorería ${ }^{24}$. Los bienes muebles dedicados al culto divino, como los adornos del altar o de la capilla, las insignias, las banderas, los estandartes y los ornamentos de las procesiones debían ser guardados en la sacristía de la iglesia, convento o capilla donde radicase la cofradía. Entre las obligaciones de los cofrades estaba el aporte en limosnas o cuotas que debían entregar al momento del ingreso a la cofradía, así como las que debían aportar a lo largo del año, según la periodicidad que se estableciese -anual, mensual o semanal-, y cuyo monto dependía del estatus económico de sus miembros. Además, los cofrades debían participar en los festejos y oficios religiosos, misas, procesiones

\footnotetext{
${ }^{22}$ Las cofradías indígenas revisten especial importancia, pues como se ha señalado sobre ellas “[...] gravitó la congregación ritual de los indígenas, la construcción de una fe popular y el surgimiento de una ritualidad que integró los elementos de la liturgia catequética romana, así como prácticas locales (ceremonias, danzas, máscaras, vestimentas, instrumentos musicales, melodías, etc.) y fueron utilizadas por las comunidades indígenas para defenderse de los ataques de que fueron objeto durante el periodo de reformismo borbónico tal y como ha sido documentado en el caso del pueblo de indios de Labateca, cuando se señala que "En la Nueva Granada el poder económico y social que habían logrado algunas cofradías fue el argumento utilizado por los indígenas para conservar sus tierras comunales tras la campana de extinción y reducción de resguardos llevada a cabo por funcionarios reales a fines del siglo XVIII”. Cfr. Díaz A., Alberto; Martínez S., Paula y Ponce, Carolina. "Cofradías de Arica y Tarapacá en los siglos XVIII y XIX. Indígenas andinos, sistema de cargos religiosos y festividades”, en Revista de Indias, 2014, vol. LXXIV, núm. 260, pp. 101128, Cruz Rangel, José Antonio. "Las cofradías indígenas en el siglo XVIII, un sistema colonial de poder, resistencia, y exacción. El caso de Chimalhualcan, Atenco", en Dimensión Antropológica, http://www. dimensionantropologica.inah.gob.mx/?p=1050 (15 de noviembre del 2015); Ferreira Esparza, Carmen Adriana. "Nuestra Señora de las Angustias del pueblo de indios de Labateca. La doble cara de la cofradía colonial", en Anuario de Historia Regional y de las Fronteras, núm. 6, Bucaramanga, Universidad Industrial de Santander, 2002, p. 458.

${ }^{23}$ Una de las cuales la tendría el rector, otra el mayordomo y la tercera uno de los diputados, los que se hacían responsables del control administrativo.

24 Martínez Domínguez, Héctor, "Las Cofradías en La Nueva España”, http://cdigital.uv.mx/ bitstream/123456789/7975/2/anua-Ipag45-71.pdf (20 de octubre del 2015), pp. 50-55.
} 
y entierros que se efectuaban en el transcurso del año, especialmente aquellas que se celebraban con motivo de la fiesta del Santo Patrono Titular, y la del Jueves y Viernes Santo.

Cuadro 1. Cofradías, Pamplona siglo XVIII.

\begin{tabular}{|c|c|}
\hline Institución & Cofradías \\
\hline \multirow{6}{*}{ Iglesia } & Hermandad de San Pedro. \\
\hline & Benditas Ánimas del Purgatorio. \\
\hline & Nuestro Amo del Señor Sacramentado. \\
\hline & Nuestra Señora de Las Nieves. \\
\hline & Misa de las Doce. \\
\hline & Santa de la Veracruz. \\
\hline \multirow{5}{*}{ Convento de Santa Clara } & Patriarca San Joseph. \\
\hline & Patrono Niño Huerfanito. \\
\hline & Nuestra Señora de Monserrate. \\
\hline & Santísima Virgen de la $\mathrm{O}$. \\
\hline & Limpia Concepción de María Santísima. \\
\hline Convento de Santo Domingo & Nuestra Señora del Rosario. \\
\hline \multirow{4}{*}{ Convento de San Agustín } & Nuestro Señor Jesús. \\
\hline & San Joseph. \\
\hline & De la Encarnación. \\
\hline & Imagen de Santa Rita. \\
\hline \multirow{2}{*}{ Convento San Juan de Dios } & Patriarca San Juan de Dios. \\
\hline & Hospitalidad de Nuestra Señora de Santa Ana. \\
\hline Compañía de Jesús & Sagrado Corazón de Jesús. \\
\hline \multirow{5}{*}{ Otras } & San Juan Bautista. \\
\hline & Santa Úrsula. \\
\hline & Nuestra Señora del Carmen. \\
\hline & Santa Lucía. \\
\hline & Virgen de Chiquinquirá. \\
\hline
\end{tabular}

Fuente: Archivo Notarial de Pamplona (ANP), ts. 70-138; Archivo Notarial de Cúcuta (ANC), ts. 1 al 12.

Los derechos a los que se accedía como miembro de la cofradía estaban directamente relacionados con el objeto de la misma, pero en general eran los de auxilio espiritual y las prácticas piadosas en casos de enfermedad y muerte, la celebración de misas anuales por los cofrades difuntos, y al socorro de los hermanos vivos en caso de necesidad. Dadas las múltiples actitudes que estimulaban estas agrupaciones religiosas, entre ellas las de la asociatividad, la solidaridad y la cohesión comunitaria, abarcar objetivos sociales como la caridad, la fraternidad y la asistencia, y facilitar el control social y la canalización de los principios catequéticos que la Iglesia y la Corona, tales como el fomento de la fe, la espiritualidad y el buen comportamiento; la fundación de estas agrupaciones fueron estimuladas y de echo tanto en las Nuevas 
Leyes de Indias (1542) como en la Recopilación de las Leyes de los Reinos de Indias (1680) se ordenaba el establecimiento de cofradías en América ${ }^{25}$.

Dado que las cofradías estaban bajo la jurisdicción de las autoridades civiles y eclesiásticas, eran objeto de supervisión en el ejercicio de las visitas eclesiásticas que se realizaban a las diferentes parroquias, conventos y comunidades y se revisaba el funcionamiento de las diferentes cofradías, su situación religiosa, el número de miembros y el cumplimiento de sus funciones y obligaciones, etc. En últimas, la visita se constituía en una inspección general que dejaba una serie de recomendaciones que eran consignadas en el Auto de la visita y que eran de obligatorio cumplimiento para los curas y mayordomos de cofradías. En el caso que ocupa, el interés se ha centrado en el diagnóstico y las recomendaciones que el visitador, doctor Don Francisco Joseph de Cabrera y Dávalos ${ }^{26}$, realizó a las diferentes cofradías que funcionaban en Pamplona para la época de la visita, julio de 1730.

Del análisis del Auto de la visita ${ }^{27}$ se infiere la coyuntura difícil por lo que estaban atravesando las cofradías en la ciudad en cuanto hace referencia al estado de veneración y fervor que tenían los fieles y en los aspectos económicos el desgreño administrativo que existía en el manejo de los bienes de las mismas, pues solo encontró referencias de 10 cofradías $^{28}$. Para tratar de remediar la situación, en lo que hace al primer aspecto, en el caso de las cofradías obligatorias, el visitador al constatar el poco fervor en el pago de limosnas y contribuciones de los feligreses, ordenó que fueran asentados todos los feligreses de la ciudad y sus confines como hermanos, para que los mayordomos cobraran en cada uno año "dos reales de plata de cada cabeza de familia y un real de las demás personas inferiores" ${ }^{29}$, además de las limosnas, que en el caso de la del Santísimo, debían cobrarse “[...] los días jueves, primeros domingos de cada mes, el día de Ramos, Jueves Santo y todas las veces que la divina majestad del santísimo sacramento saliere por modo de Beatico" ${ }^{30}$. Esta situación general se puede ejemplificar con el caso de la cofradía de Nuestra Señora de las Nieves, que había sido adoptada oficialmente como la Patrona de la ciudad, pues no tenía principal alguno,

${ }^{25}$ Díaz A., Alberto; Martínez S., Paula y Ponce, Carolina. "Cofradías de Arica y Tarapacá en los siglos XVIII y XIX. Indígenas andinos, sistema de cargos religiosos y festividades”, en Revista de Indias, vol. LXXIV, núm. 260, 2014, pp. 101-103.

${ }^{26}$ El doctor Cabrera y Dávalos era Calificador del Santo Oficio, Maestre de la escuela Dignidad de la Santa Iglesia Metropolitana de la ciudad de Santafé, juez oficial proveedor y vicario general y visitador del Arzobispado.

${ }^{27}$ El notario de la Visita que terminó el 23 de febrero de 1731 fue Vicente Ignacio Torres. Esta Visita se encuentra en la Biblioteca Luis Ángel Arango, microfilm del Archivo Arquidiocesano de Pamplona, sin foliar, por lo que se imposibilita citar en este artículo los folios específicos cuando se hace referencia a casos o situaciones puntuales.

${ }^{28}$ Entre 1700 y 1760, cinco cofradías tuvieron como fin principal cubrir gastos de celebración (Señora de la Encarnación, Jesús Nazareno, San Joseph y San Francisco), siete para alumbrar las imágenes promovidas por los conventos asentados en la ciudad, y solo una obra pía fue destinada a la reconstrucción del templo, el de la Ermita del Humilladero, la de Juana López Morante por \$2.000. Ferreira Esparza, Carmen Adriana, Op cit., p. 35 .

29 Ibid.

${ }^{30}$ Ibid. 
por lo que no se llevaba libros de cargo y data y había decaído el fervor con el cual se celebraban sus fiestas. Otras cofradías estaban prácticamente extinguidas como la del Niño Jesús, la del Humilladero, la de Señor San Benito ${ }^{31}$ y la de Nuestra Señora de la Encarnación cuyas constituciones no habían sido confirmadas. En la mayor parte de los casos el visitador no encontró en los archivos de las cofradías ni sus libros de constitución, ni tampoco los de cargo y data.

Al revisar los libros de ingresos y de egresos, el visitador detectó también una serie de irregularidades en el manejo de los bienes de las cofradías, sobre todo en lo relacionado con los bienes hipotecados que respaldaban los diferentes censos otorgados. De hecho, el capital o el principal que reportaron fueron relativamente bajos, pues a excepción de la Hermandad de San Pedro (HSP) que señaló la suma de $\$ 28.032$, la de las Benditas Ánimas fue de \$1.945, la de Nuestra Señora de la Concepción $\$ 1.070$, la del Santísimo Sacramento $\$ 680$ y la de la Santa Vera Cruz ${ }^{32}$ fue de apenas de \$200. Hay que señalar que no siempre coincidió la cifra reportada en el principal o capital de las capellanías con los montos que tenían otorgados en los créditos. En el caso de la cofradía de las Benditas Ánimas se presentó una diferencia de $\$ 300$, en el de Nuestra Señora de la Concepción de \$700 y en la de la HSP de \$23. 282, situación explicada por la existencia de censos a los cuales no se les hacía mayor seguimiento y estaban perdidos, o porque no se reportaron todos los censuarios como en el caso de la cofradía de la HSP. Así por ejemplo, de los tres censos que le debían a la Cofradía del Santísimo, uno de ellos, por \$210, había sido tomado en 1722 y respaldado solamente con un vale a pagar en dos años, lo cual no habían hecho como tampoco había pagado los réditos, otro censo otorgado a un vecino de la ciudad de Santafé, estaban dados al:

[...] ad honestum lucrum y de él no se tenían noticias; en la cofradía de las Benditas Ánimas, los mayordomos resultaron tener cuentas atrasadas con la misma cofradía y algunos de los 12 censos estaban impuestos sobre bienes urbanos que se habían deteriorado; el caos administrativo de la cofradía de Nuestra Señora de la Concepción era aún más lamentable, pues la memoria de las rentas se había perdido, algunas rentas se habían dejado de percibir, las

\footnotetext{
${ }^{31}$ El mayordomo señaló que los hermanos a su entrada daban dos reales, y un real cada año, y las Priostas y mayordomos que se elegían para celebrar la fiesta daban cada uno $\$ 1$, media libra de cera, media arroba de cebo y una onza de inciencio, y los Alfares cada uno \$2, una libra de cera, media de sebo y una onza de inciencio.

${ }^{32}$ Esta cofradía estaba situada sobre la Hermita del Humilladero y los bienes de la compañía estaban reducidos a lo que recibía por cargo del alquiler de una tienda y del rédito de \$200 que tenía impuestos en la ciudad de San Juan Girón, y de lo que percibiera por entrada de cofrades ( $\$ 1$ los hombres y 4 reales las mujeres) más los tercios anuales que pagan los hermanos. En cuanto a sus orígenes se refiere, se dice que hacia el año 320 la Emperatriz Elena de Constantinopla encontró la Vera Cruz, la cruz en que murió Nuestro Señor Jesucristo, la Emperatriz y su hijo Constantino hicieron construir en el sitio del descubrimiento la Basílica del Santo Sepulcro. Matos Hurtado, Belisario. "Apuntaciones y documentos para la historia de Pamplona: La Cofradía de la Santa Veracruz y el Santo Crucifijo del Humilladero", en Boletín de Historia y Antigüedades, vol. XXXI, núm. 39, Bogotá, 1944, pp. 7-35.
} 
alhajas de la virgen no se encontraban y había sospecha que eran usadas como adorno por particulares ${ }^{33}$.

No se llevaban actualizados los libros de la cofradía y solo se entregó un libro de cuentas que tenía una relación de las rentas del año de $1.700^{34}$.

En cuanto a la cofradía de la hermandad de nuestro padre San Pedro, esta era la más rica e importante de la ciudad de Pamplona, también era la cofradía más organizada pues tenía, en forma independiente sus libros de constitución y de actas del cabildo, y el de ingresos y gastos que llevaban los mayordomos ${ }^{35}$. El primer hallazgo del visitador, al revisar las cuentas del doctor Don Pedro Rendón Sarmiento, que había sido mayordomo durante 5 años (1723-1728), era que la cofradía solo había recibido ingresos por $\$ 466$ y realizados gastos por $\$ 1.110$, tomando la diferencia de $\$ 644$ de los principales manejados por la cofradía. Por su parte los mayordomos que lo habían reemplazado en el año de 1729, el maestro Don Antonio de León y Don Francisco Guerrero, también señalaron un déficit de $\$ 959,4$, pues habían pagado a los capellanes, arreglado la capilla y cubierto los gastos ordinarios, sin haber cobrado a tiempo los réditos, y esto gastos los habían sido asumido dichos mayordomos; lo que de alguna manera sirvió para que el visitador los dejase continuar desempeñando el cargo de mayordomos $^{36}$. El visitador, además de ordenar el pago de dicho déficit, estipuló que en adelante, solo se dijeren las misas correspondientes a los réditos cobrados y que bajo ningún pretexto, los mayordomos o la hermandad podían destinar para gastos y pagos, dinero de los principales de las Capellanías; y que los capellanes debían esperar hasta que se cobraran los réditos de las capellanía a su cargo para poder cobrar sus honorarios. También criticó los gastos excesivos que se hacían en vino y cera, por lo que ordenó que para cubrir dichos gastos, solo debía darse un real anual por cada misa

\footnotetext{
${ }^{33}$ El visitador mantuvo vigente y reorganizó la cofradía con algunas normas: que los feligreses devotos dieran de limosna en su entrada dos reales y un real cada año, que se celebrara la fiesta de la Virgen cada 8 de diciembre, y en las vísperas se hiciera procesión, sermón y misa cantada, y que por ello se le diera $\$ 12$ de estipendio al cura y $\$ 8$ al predicador, y que se hiciera cada tercer domingo del mes una misa cantada en el altar de la santísima Virgen. Además el cura debía celebrar, en el mes de noviembre el aniversario por los hermanos difuntos, cantar la vigilia, la misa y responsos, por lo cual recibía $\$ 6$ de estipendio, y por cada hermano que muriere debía decir una misa rezada, solamente por 4 reales, dada la pobreza de la cofradía.

${ }^{34}$ A partir de este libro de cuentas se pudo reconstruir algunas de las acreencias de la cofradía: Juan Galavis le debía $\$ 250$, censo que había sido traspasado a Jacinto Díaz, su fiador, el Dr. Don. Juan de Figueroa, debía \$220 de la venta de un solar en la ciudad de Cartagena, Aunque las partidas iniciales sumaron \$1.070, había otras partidas por $\$ 800$ que aún faltaban por aclarar el estado de su situación, entre ellas, una por $\$ 500$ de Juan Pinedo, por rentas sobre tres tiendas que tenía la cofradía en la Plaza de Pamplona, de ellas, dos tenían escrituras de donación, otorgadas por Don Nicolás de Pinedo en satisfacción de \$500 que había de dar de los bienes del capitán Juan Gómez de Villalobos, y la otra tienda había sido entregada por Catarina Quintero en pago de $\$ 100$ pesos que debía Matías del Rincón, su marido difunto. Otros \$100 de Don Joseph de Araque, que redimió y entregó su mujer Doña Catarina de Figueroa, y \$200 de Vicente Bustos.

${ }^{35}$ La visita anterior se había efectuado hacía 7 años.

${ }^{36}$ Los bienes y alhajas de la cofradía estaban a cargo de Juan Alberto Albarracín, sacristán de la iglesia parroquial.
} 
que debían oficiar los capellanes ${ }^{37}$. Además, las redenciones de los principales debían hacerse ante el vicario juez eclesiástico, estando presente el notario de la cofradía y que las sumas redimidas debían entregarse al mayordomo, para que se guardaran en la caja de tres llaves hasta colocarlos a censo, para lo cual el vicario debía colocar avisos, señalando la cantidad de dinero a imponer y exigiendo la entrega de fianzas a satisfacción de la hermandad ${ }^{38}$

La cofradía tenía un capital de $\$ 28.302$ que le redituaba anualmente $\$ 1.415$, más el rédito de la hacienda de la mata Redonda, de cuyo producido se debían sacar $\$ 180$ anuales para el capellán de la capellanía que había fundado su propietaria Doña Leonor Cortes por valor de \$3.600; y \$200 para el administrador de la hacienda ${ }^{39}$. La hermandad también tenía derecho a las tierras de Icota, que pertenecían a Don Luis Camacho de Rojas y este las había hipotecado por \$200, y al momento de su muerte no tenía otros bienes en cuales soportarlos. Igualmente era de propiedad de la cofradía un fondo de más de cuatro arrobas y metal de hierro, el cual se ordenó que se vendiera y su importe se impusiera a censo. Es de anotar que en el caso de esta cofradía, en el libro de actas de la visita solo se hizo referencia a aquellos deudores y censos que registraban algún tipo de problemas, como litigios por bienes hipotecados, censuarios y fiadores insolventes, casos en los cuales había que proceder con el recaudo de principales o la presentación de nuevos fiadores, etc. ${ }^{40}$ Ello es lo que

\footnotetext{
${ }^{37}$ Así por ejemplo, al capellán de la capellanía de Doña Leonor Cortes que debía celebrar 80 misas en el Altar de Nuestra Señora de Monserrate, en la iglesia del convento de Santa Clara se le darían \$10 para que cubriera sus gastos.

${ }^{38}$ Es de anotar, que en la segunda mitad del siglo XVIII se incrementó el control que la Corona ejercía sobre las Cofradías, para lo cual impulsó una serie de reformas que buscaban extender la jurisdicción de la Corona sobre ellas, desplazando a la eclesiástica, y redefiniéndolas como "cuerpos de legos". Más la reforma contempló también la reducción de los gastos de culto en beneficio de la caridad y, la supresión de toda forma de obligación, retribución o vanidad profana, en beneficio del desinterés y la voluntariedad propias de las que llamaban también Congregaciones piadosas. Aunque en la visita de 1730 se formularon recomendaciones al respecto, el no hallazgo de otras visitas posteriores impidió verificar si las recomendaciones se habían cumplido o no. Carbajal López, David. "La reforma de las cofradías en el siglo XVIII: Nueva España y Sevilla en comparación”, en Revista Complutense de Historia de América, vol. XXXVIII, Madrid, 2012, p. 79.

${ }^{39}$ En el cabildo de la cofradía celebrado el 5 de agosto de 1730, se decidió que la administración estuviera a cargo de un hermano sacerdote al que se le reconocerían los \$200 los cuales debían ser repartidos entre todos los hermanos con el cargo de decir 100 misas rezadas. Para la época se encargó de la administración al maestro Antonio de la Peña.

${ }^{40}$ Así entonces se señalan los casos de Joseph Amaya con un censo de \$200, respaldados sobre unas tierras en el Valle de Servita, que estaban en litigio por haber sido dadas a los indios de Balegra; a Doña Juana Ángela del Castillo, quien se había hecho responsable por la deuda de su marido, el gobernador Don Joseph Enciso, que había fallecido y el censo estaba impuesto sobre unas tierras en el llano jurisdicción de Tequia, que también estaban en pleito; a Don Francisco de Arce y Ceballos, como fiador de Don Francisco Sánchez Montaño, porque este no tuvo bienes con que seguir respaldando el censo por \$50; a Juan Morales que era deudor de $\$ 1.500$ y debía presentar un nuevo fiador; a Isidro Pacheco que debía especificar el número de estancias que componían las tierras dadas en hipoteca a la cofradía por un censo de \$200; a Juan Rangel que debía aportar un nuevo fiador para poder continuar con el censo de $\$ 140$; además de cobrar $\$ 1.500$ que estaban impuestos en la ciudad de Cartagena, sin tener mayores noticias ni de réditos, ni del principal, con la orden expresa de que una vez ello sucediera, se impusiera a censo en la jurisdicción de la ciudad de Pamplona.
} 
explica que mientras el monto de capital ascendió a $\$ 2.302$, la relación de censuarios solo alcanzaba los $\$ 4.896$, y $\$ 224$ que había en efectivo en caja, producto de algunos censos que habían sido redimidos.

\section{El crédito cofriadal en la provincia de Pamplona, siglo XVIII ${ }^{41}$}

La diversificación de la estructura productiva de la región, con la conformación y la consolidación de las unidades de producción de las haciendas, la incorporación de las formas de trabajo esclavo, el desarrollo de redes comerciales y la ampliación urbana de la ciudad, villas y parroquias, demandó importantes cantidades de capital durante el siglo XVIII, el cual fue surtido mediante préstamos o censos ${ }^{42}$ tomados en la economía local y préstamos de comerciantes de la carrera interesados en asegurar el comercio del cacao, además de todos aquellos censos que se configuraban para acceder a la propiedad territorial rural, mejorar el utillaje y los bienes urbanos, cuando no para ascender en la escala social y las redes de poder político local.

Pero, al ser la falta de liquidez monetaria una de las características centrales de la economía colonial, sobre todo en aquellas regiones no vinculadas con la producción aurífera, ¿de dónde provinieron entonces los recursos de capital para atender este incremento en la demanda de crédito que se dio en el siglo XVIII en la región? La respuesta se encuentra en la estructura misma de la sociedad colonial, imbuida de una mentalidad religiosa que había instrumentado la concepción de la vida terrenal como un simple paso hacia la vida eterna y por lo tanto construida la idea de la necesidad

\footnotetext{
${ }^{41}$ Este estudio se apoyó fundamentalmente en las escrituras de censos y capellanías que quedaron consignadas en el Archivo Notarial de Pamplona en el siglo XVIII. Estas escrituras permitieron establecer las características de los que prestaban y pidieron créditos, así como las relaciones entre los diferentes sectores involucrados (Iglesia, elite, pequeños productores de cacao, comerciantes, etc.), los montos, el origen de la deuda, es decir si se trataba de un censo, un depósito irregular, u otro mecanismo crediticio, los bienes hipotecados, en caso de que los hubieran, y en algunas ocasiones se menciona el destino del capital prestado. Asimismo, fue posible determinar los cambios y las tendencias predominantes durante el periodo analizado a través de la elaboración de cuadros y gráficos estadísticos, para señalar a través de las cifras la transición hacia nuevos mecanismos crediticios. También se consultó el fondo Cofradías y capellanías del Archivo Arquidiocesano de Pamplona y los fondos de Capellanías, Censos y Conventos del Archivo General de la Nación, para analizar los posibles conflictos que se presentaron alrededor de las diferentes instituciones crediticias y el impacto que tuvieron los censos en la economía regional. No se encontró informes de nuevas visitas pastorales ni fue posible consultar los libros de cuentas de las instituciones eclesiásticas, para ampliar la visión sobre las redes de crédito establecidas y el manejo de la riqueza acumulada por estas instituciones, dado que en Colombia los archivos de los conventos y órdenes religiosas son de carácter privado y no un bien patrimonial de uso público que permita fácilmente el acceso a los investigadores.

42 "La figura del censo consiste en esencia en una obligación que gravita sobre el titular de una finca, de pagar a otra persona un canon o rédito anual, es decir, una cantidad determinada de dinero o de otras cosas fungibles. La causa de que procede esta obligación puede ser muy varia, pero en todo caso se ha de partir de la base de que no se trata de una mera obligación personal [...] si no que es, por el contrario, una carga perpetua que gravita sobre las fincas, vinculando propter rem a sus sucesivos propietarios, que solo en cuanto y mientras conservan su titularidad, están obligados a pagarla". Martínez López-Cano, Pilar (comp.). Iglesia, estado y economía. Siglos XVI al XIX (México: UNAM, Instituto de Investigaciones Dr. José María Luis Mora, 1995).
} 
de la salvación del alma a través de los legados piadosos ${ }^{43}$, el reconocimiento de los santos intercesores y la capacidad y funcionalidad de las plegarias de intercesión. Así entonces, poco a poco, la Iglesia, encargada de administrar estos legados y de hacer cumplir la última voluntad de quien hubiera establecido el legado, fue haciéndose depositaria de dinero y bienes que tuvo que invertir para hacerlos rentables y no afectar ni el monto establecido, ni el número de plegarias o las obligaciones adquiridas. Pero además, las fundaciones piadosas cumplían otras funciones: realzaban el estatus social de los donantes, contribuían a estrechar el tejido de estructuración de redes de poder de las élites locales y aseguraban la indivisibilidad de algunos bienes y la existencia de una masa de capital a la cual se podía acceder en caso de necesidad y en determinadas circunstancias.

\section{Las cofradías y el crédito en la ciudad de Pamplona, siglo XVIII}

Frente a la recepción y acumulación de dinero y bienes en manos de las diferentes órdenes religiosas, las necesidades de capital para potenciar las actividades económicas y la importancia que iban tomando tanto la actividad comercial y los comerciantes en la sociedad, etc., las posiciones dogmáticas frente a la usura que pregonaron muchos padres de la Iglesia, como San Agustín y Santo Tomás, fueron cediendo ${ }^{44}$. Ya para finales del siglo XV se aceptó la idea de la ganancia, o del cobro de un interés en el sector financiero, bajo la figura del censo consignativo, y en adelante la discusión giró sobre el monto justo al cual debía ascender dicho interés, llegando a estabilizarse en el $5 \%$ o 20.000 el millar.

Dada la escasez de dinero en efectivo (usual y corriente) durante la época colonial, especialmente en las zonas no mineras, el crédito cumplió un papel fundamental en el desarrollo económico de vastas regiones, al suplir la necesidad de liquidez de capital $^{45}$, pues buena parte de las transacciones económicas implicaban alguna operación crediticia, dado que empresarios y comerciantes solicitaban préstamos en forma periódica para mantener operando sus unidades productivas y realizar sus transacciones comerciales, en tanto que los sectores de la sociedad venidos a menos lo hacían para tratar de mantener su estatus, pero ¿de dónde provenían los recursos para financiar el sistema crediticio? Ante la inexistencia de instituciones especializadas en ofrecer créditos, estos recursos provenían de redes informales que seguían los cauces de las lógicas de la acumulación de los sectores dominantes, siendo las instituciones

\footnotetext{
${ }^{43}$ Esta práctica fue instaurada por la Iglesia católica a fines del siglo XII, pues como señala Arias, para la sociedad el dilema era claro: "[...] o bien no cesar de gozar la temporalia, hombres y cosas, y perder su alma, como lo decían los hombres de Iglesia y toda la tradición cristiana, o bien renunciar a ellos y ganar su salvación eterna: temporalia aeterna". Aries, Philippe. El hombre ante la muerte (Madrid: Taurus, 1983), p. 163.

${ }^{44}$ Schumpeter, Joseph Alois. Historia del Análisis Económico (Barcelona: Ariel, 1971), pp. 142-146.

${ }^{45}$ Contrariamente a lo que han señalado algunos estudios sobre el obstáculo que representaba el crédito para el desarrollo económico, al enquistarse en las unidades productivas como pesados gravámenes, siendo muy pocas veces redimidos; los avances más recientes de la historiografia sobre el tema han demostrado que, al menos para el caso mexicano, el crédito dinamizó la economía colonial.
} 
eclesiásticas (conventos, capellanías y cofradías) los principales agentes crediticios $^{46}$, aunque en la segunda mitad del siglo XVIII adquirió importancia el crédito comercial, es decir, los créditos entre particulares, especialmente de los sectores ligados al comercio, la minería o la agroexportación, lo que contribuyó a la disminución del monopolio que sobre el sector financiero ejercía la Iglesia, la cual fue, de manera gradual, desplazada por el capital comercial.

Aunque se reconoce la existencia de diversos tipos de $\operatorname{censos}^{47}$, en primer lugar la diferenciación existente entre los censos -préstamo que se establecían al prestar dinero en efectivo y los censos- gravamen que se fijaban cuando se transfería un bien gravado o hipotecado, y la clasificación de los censos desde el punto de vista jurídico como consignativo, enfitéutico y reservativo, el análisis desarrollado para los censos otorgados a partir de las cofradías, solo se refirió a sus aspectos generales, pues de lo que se trataba era de establecer su incidencia en la economía de la provincia y no sus especificidades en forma particular.

En el caso de la ciudad de Pamplona y su jurisdicción durante el siglo XVIII, se efectuaron 3.395 censos $^{48}$ por un valor total de $\$ 1^{\prime} 926.395$, con especial énfasis en

\footnotetext{
${ }^{46}$ Durante los dos primeros siglos del periodo colonial la Iglesia había monopolizado el escaso dinero circulante mediante la captación de legados piadosos; de esta manera, a través del funcionamiento del crédito, se estableció una estrecha relación simbiótica entre la Iglesia y las élites, pues gran parte de los bienes de aquella provenían de los caudales acumulados por estas últimas y legados a la Iglesia en forma de capellanías, obras pías y donaciones. A su vez, las élites se beneficiaban del crédito otorgado por la Iglesia para desarrollar sus actividades productivas, incrementar el patrimonio material y estrechar sus vínculos sociales y políticos, aunque hay que señalar que la expansión del cultivo del cacao en la región posibilitó que pequeños préstamos fueran invertidos en el desarrollo de esta actividad y beneficiara a pequeños productores cacaoteros, quienes se habían convertido en arrendatarios y aparceros de las grandes haciendas, ubicadas especialmente en el valle de Cúcuta. En cierta medida esta forma de crédito facilitó el establecimiento de nuevas relaciones entre los hacendados, que habían logrado cierto nivel de acumulación de tierra, y los pequeños productores sin tierra, quienes dependían, cada vez más, de los hacendados y comerciantes para reproducirse y participar del ciclo de la producción. Es de anotar que esta dinámica incidió para que se fueran reemplazando los censos perpetuos por censos a corto plazo que solo requerían de fiadores para respaldar el préstamo. Guerrero Rincón, Amado Antonio, Op. cit., pp. 300-350.

${ }^{47}$ Según Escriche, censo es el "[...] derecho de percibir una pensión anual, mediante la entrega de una cosa”. Podía ser de tres clases: enfitéutico, reservativo y consignativo. Para María del Pilar Martínez López Cano el censo enfitéutico se configuraba cuando el censualista transfería un bien mueble o inmueble reservando para sí el dominio ante el censuario, quien quedaba obligado a pagar su renta anual; el censo reservativo también se hacía sobre un bien, pero el censualista daba el bien a dominio del censuario, generalmente a perpetuidad o a larga duración; finalmente, estaba el censo consignativo, por medio del cual el censualista prestaba dinero en efectivo, y el censuario hipotecaba un bien mueble o inmueble. Este último, cuando se pagaba en frutos, constituyó el censo consignativo fructuario, y cuando se hacía en dinero, el censo consignativo pecuniario. Martínez López-Cano, Pilar; Von Wobeser, Gisela y Muñoz, Juan Guillermo (coords.), Op. cit., p. 14.

${ }^{48}$ Los censos se convirtieron en la manera como la Iglesia mantuvo el dinero y los bienes recibidos funcionando dentro del sistema económico de la época, siendo esta la forma natural que adoptó el crédito, pues era "[...] el derecho de recibir una pensión sobre una cosa que pertenecía al que se sujetó al pago de la misma", concepción que permanecería durante los siguientes siglos, pues como anota Colmenares, no solo se acomodaba a los ritmos lentos de una economía agraria de lenta recuperación de los capitales invertidos, a veces una o dos generaciones, sino que también privilegiaba a una clase: los terratenientes, permitiéndoles canalizar el escaso circulante hacia sus empresas. Colmenares, Germán. Cali: Terratenientes, mineros y comerciantes, Siglo XVIII (Bogotá: Banco Popular, 1983), pp. 82 y 104.
} 
el periodo de 1760-1800 cuando se realizaron el 56,9 \% de los préstamos ${ }^{49}$. En las operaciones crediticias fueron predominantes los censos provenientes de los sectores religiosos (conventos, capellanías, cofradías, curas y rentas parroquiales) cuyo número fue superior al $80 \%$ del total de los casos del siglo y en cuanto a los montos se refiere, la participación de este sector fue del $64 \%$ frente al $36 \%$ de los créditos particulares (tutelas y el otorgamiento y reconocimiento de censos interpersonales ${ }^{50}$ ). Dado el desempeñó activo de la Iglesia en el mercado financiero colonial y el desarrollo de la vocación rentística de esta institución ${ }^{51}$, no es de extrañar que sea considerada por muchos autores como el banco de la época y por otros como el principal banco agrícola $^{52}$ (Cuadro 2.).

En cuanto a las cofradías se refiere, las cuales estaban conformadas por grupos de personas que tenían como finalidad la asistencia social -material- y espiritual de sus miembros, estas se constituyeron en una importante fuente de financiamiento de los créditos de la región y en particular del sector agrícola. De hecho, manejaron el $12,9 \%$ del número de censos otorgados por un valor equivalente al $12,5 \%$ del total de los préstamos concedidos en la ciudad de Pamplona en el siglo XVIII ${ }^{53}$. Su participación tuvo altibajos a lo largo del siglo: fue creciente durante las décadas de 1700 a 1739, decreciente en las dos siguientes y se recuperó a partir de 1760, cuando el promedio decenal comenzó nuevamente a incrementarse hasta el final del siglo. Aunque en el otorgamientos de censos participaron diferentes cofradías como la de

\footnotetext{
${ }^{49}$ En el estudio general sobre el crédito, metodológicamente se dividió el siglo en tres periodos: el primero comprendió las primeras cuatro décadas, en las cuales los créditos fueron en ascenso y en total se realizaron el 27,8\% de los censos (939 casos); el segundo abarca las dos siguientes décadas de inflexión, pues el número de operaciones disminuyó y se realizaron apenas el 15,4\% de los censos (524); y el tercero, que comprendió las últimas cuatro décadas, en el cual el número de censos aumentó de manera constante, de modo que en este periodo se realizó el 56,9\% de las operaciones crediticias (1.932 casos).

${ }^{50}$ De la Real Hacienda también provinieron algunos recursos que pudieron alimentar el capital de la región, como cuando se le remataron los bienes confiscados a los jesuitas, pero no se encontró mayor evidencia de que este capital se utilizara como fuente de recursos para otorgar censos, aunque las haciendas fueron rematados entre los vecinos.

${ }^{51}$ De esta generalidad hay que exceptuar a la orden religiosa de la Compañía de Jesús, la cual, a través de sus colegios, administraba sus empresas y participaba activamente en los ciclos de producción, y a la cual se le debe el inicio del cultivo del cacao en la región. Sobre tierras obtenidas por Real Cédula de su majestad, establecieron arboledas de cacao utilizando el sistema de regadío y fuerza de trabajo esclavo, de tal forma que entre los años de 1657 y 1664, recogieron 41.829 millares de cacao, unas setecientas cargas, procedentes de la hacienda San Francisco Xavier, ubicada en la jurisdicción de la ciudad de Gibraltar. En otras regiones también eran propietarios de haciendas como las de El Trapiche y la de San Xavier de la Vega, ubicadas en Cúcuta, que exportaban sus cacaos por Maracaibo y las cuales fueron rematadas, en 1771, en \$28. 000 cada una; en Honda tenían las haciendas de Fierro Arriba y Fierro Abajo, con más de 40.000 árboles de cacao y la hacienda de Chipalo de San Juan de la Vega, ubicada a orillas del río Magdalena. También tenían haciendas de cacao en Mompox y en Ocaña. Tovar Pinzón, Hermes. "El cacao en la sociedad colonial llegó a ser el primer producto agrario de exportación”, en Revista Credencial Historia, núm. 130, Bogotá, 2000; Colmenares, Germán. "Censos y capellanías. Formas de crédito en una economía agrícola”, en Cuadernos Colombianos, núm. 2, Bogotá, 1974, pp. 123-144.

${ }^{52}$ Bauer, Arnold. La iglesia en la economía de América Latina siglos XVI al XIX (México: Instituto Nacional de Antropología e Historia, 1986).

${ }^{53}$ En relación con los sectores religiosos, en la Provincia de Pamplona, las cofradías representaron el 32,2\% de número de censos otorgados y el 19,5\% de los montos de capital.
} 
las Benditas Ánimas del Purgatorio, Santísimo Sacramento, Nuestra Señora de las Angustias, Nuestra Señora de las Nieves, Nuestra Señora de la Concepción, Cristo del Humilladero, Santo Ecce Homo, Nuestra Señora del Rosario de Cucutilla, etc., la más importante fue la cofradía de la Hermandad de San Pedro de la ciudad de Pamplona, tal y como se desprende de la información archivística sintetizada en el Cuadro 3.:

Cuadro 2. Crédito en la provincia de Pamplona, siglo XVIII.

\begin{tabular}{|c|c|c|c|c|c|c|c|c|c|c|}
\hline \multicolumn{5}{|c|}{ Instituciones y sectores religiosos } & \multicolumn{4}{c|}{ Particulares } & \multicolumn{3}{c|}{ Total créditos } \\
\hline Década & Núm. & $\%$ & Valor & & Núm. & $\%$ & Valor & $\%$ & Núm. & Valor \\
\hline $1700-09$ & 150 & 89,3 & 66135 & 83,2 & 18 & 10,7 & 13382 & 16,8 & 168 & 79517 \\
\hline $1710-19$ & 200 & 87,0 & 75618 & 71,5 & 30 & 13,0 & 30228 & 28,5 & 230 & 105846 \\
\hline $1720-29$ & 202 & 87,8 & 82441 & 78,0 & 28 & 12,2 & 23185 & 22,0 & 230 & 105626 \\
\hline $1730-39$ & 272 & 87,4 & 115670 & 81,8 & 39 & 12,6 & 25689 & 18,2 & 311 & 141359 \\
\hline $1740-49$ & 249 & 89,2 & 118206 & 84,1 & 30 & 10,8 & 22291 & 15,9 & 279 & 140497 \\
\hline $1750-59$ & 204 & 83,3 & 112566 & 45,6 & 41 & 16,7 & 134015 & 54,3 & 245 & 246581 \\
\hline $1760-69$ & 285 & 75,6 & 142590 & 54,1 & 92 & 24,4 & 120904 & 45,8 & 377 & 263494 \\
\hline $1770-79$ & 364 & 75,8 & 183220 & 70,7 & 116 & 24,2 & 75882 & 29,2 & 480 & 259102 \\
\hline $1780-89$ & 350 & 76,6 & 162146 & 55,4 & 107 & 23,4 & 130756 & 44,6 & 457 & 292902 \\
\hline $1790-99$ & 447 & 72,3 & 173816 & 59,5 & 171 & 27,6 & 118220 & 40,4 & 618 & 292036 \\
\hline Total & 2723 & & 1232408 & & 672 & & 694552 & & 3395 & 1926960 \\
\hline $\begin{array}{c}\text { \% por } \\
\text { sectores }\end{array}$ & 80,2 & 64,0 & & & 19,8 & & 36,0 & 100,0 & 100,0 \\
\hline
\end{tabular}

Fuente: Archivo Notarial de Pamplona (ANP), ts. 70-138, Archivo Notarial de Cúcuta (ANC), ts. 1 al 12. Núm.: Número; \%: Porcentaje

Cuadro 3. Censos otorgados con recursos de las cofradías.

\begin{tabular}{|c|c|c|c|c|c|c|c|c|c|c|c|c|c|c|c|c|c|c|}
\hline \multirow{2}{*}{ Década } & \multicolumn{2}{|c|}{ HSP } & \multicolumn{2}{|c|}{ BAP } & \multicolumn{2}{|c|}{ SS } & \multicolumn{2}{|c|}{ NSA } & \multicolumn{2}{|c|}{ NSN } & \multicolumn{2}{|c|}{ NSC } & \multicolumn{2}{|c|}{$\mathrm{CH}$} & \multicolumn{2}{|c|}{ Otras } & \multicolumn{2}{|c|}{ Totales } \\
\hline & Núm. & Val & Núm. & Val & Núm. & Val & Núm. & Val & Núm. & Val & Núm. ${ }^{\circ}$ & Val & Núm..$^{\circ}$ & Val & Núm. ${ }^{\circ}$ & Val & Núm. & Val \\
\hline 1700-09 & 36 & 12510 & 7 & 875 & 1 & 200 & - & - & - & - & 1 & 100 & - & - & 4 & 1450 & 49 & 15135 \\
\hline 1710-19 & 33 & 12618 & 13 & 1881 & - & - & - & - & - & - & 5 & 680 & - & - & 1 & 200 & 52 & 15379 \\
\hline $1720-29$ & 41 & 12406 & 5 & 731 & - & - & - & - & - & - & 1 & 250 & - & - & - & - & 47 & 13387 \\
\hline 1730-39 & 55 & 18289 & 12 & 2400 & 2 & 600 & - & - & - & - & 3 & 440 & - & - & 3 & 755 & 75 & 22484 \\
\hline $1740-49$ & 29 & 9105 & 8 & 1590 & 7 & 2400 & - & - & 2 & 170 & 3 & 700 & - & - & 2 & 400 & 51 & 14365 \\
\hline $1750-59$ & 29 & 7492 & 10 & 1395 & 1 & 100 & - & - & 1 & 200 & 2 & 1050 & 1 & 200 & 4 & 1250 & 48 & 11687 \\
\hline $1760-69$ & 34 & 14507 & 24 & 3470 & 5 & 1400 & - & - & 3 & 400 & 1 & 100 & 3 & 1225 & 4 & 900 & 74 & 22002 \\
\hline $1770-79$ & 50 & 19115 & 34 & 4240 & 9 & 2880 & 21 & 2760 & 9 & 3170 & 5 & 900 & 6 & 1950 & 3 & 500 & 137 & 35515 \\
\hline $1780-89$ & 27 & 14442 & 42 & 6645 & 5 & 4100 & 23 & 5120 & 8 & 1125 & 5 & 950 & 2 & 300 & 10 & 1780 & 122 & 34462 \\
\hline $1790-99$ & 104 & 34722 & 46 & 6524 & 6 & 1275 & 22 & 4188 & 23 & 3950 & 6 & 1320 & 4 & 500 & 12 & 3844 & 223 & 56323 \\
\hline Totales & 438 & 155206 & 201 & 29751 & 36 & 12955 & 66 & 12068 & 46 & 9015 & 32 & 6490 & 16 & 4175 & 43 & 11079 & 878 & 240739 \\
\hline Porc. & 49,9 & 64,5 & 22,9 & 12,4 & 4,2 & 5,4 & 7,5 & 5,0 & 5,2 & 3,7 & 3,6 & 2,7 & 1,8 & 1,7 & 4,9 & 4,6 & 100,0 & 100,0 \\
\hline Prom. & & 354,4 & & 148,0 & & 359,9 & & 182,8 & & 195,9 & & 202,8 & & 260,9 & & 257,6 & & 274,2 \\
\hline
\end{tabular}

HSP: Hermandad de San Pedro; BAP: Benditas Ánimas del Purgatorio; SS: Santísimo Sacramento;

NSA: Nuestra Señora de las Angustias; NSN: Nuestra Señora de las Nieves; NSC: Nuestras Señora de la Concepción; CH: Cristo del Humilladero.

Fuente: Archivo Notarial de Pamplona, ts. 70-138, Archivo Notarial de Cúcuta, ts. 1 al 12.

Núm.: Número; Val: Valor; Por: Porcentaje; Prom: Promedio 
La hermandad de San Pedro, a la cual estaban ligados la mayoría de los clérigos de la región, realizó el 49,9\% de los censos otorgados por las cofradías, cuyos montos representaron el $64,5 \%$ del total. Su mayor participación se dio durante la primera mitad del siglo ${ }^{54}$ y en la década de 1790-1799, cuando prestó el mayor número de censos, en el periodo de 1740-1759, el número de censos otorgados por esta cofradía bajó, la participación en los montos no disminuyó, lo que sí ocurrió en la década de 1780-1789, cuando su participación con respecto del monto prestado por las cofradías, bajó a solo el $42,1 \%$ del total. La segunda cofradía en importancia fue la de las Benditas Ánimas del Purgatorio que realizó 201 censos $(22,9 \%)$ por un valor de $\$ 29.751$ (12,4\%), seguida de la del Santísimo Sacramento con 36 operaciones de crédito (4,2\%) por un valor de $\$ 12.955(5,4 \%)$; el resto de cofradías adquirieron alguna relevancia en el último tercio del siglo XVIII. En cuanto a los promedios de las cantidades prestados mediante censos se refiere, estos no fueron muy altos, siendo los mayores el de la cofradía del Santísimo Sacramento con \$359 y la Hermandad de San Pedro con $\$ 354$ y los más bajos los de las Benditas Ánimas del Purgatorio con $\$ 148$ y Nuestra Señora de las Nieves con $\$ 195$, lo que de alguna manera señala que las cofradías no manejaban grandes capitales, si se exceptúa la de la hermandad de San Pedro; y que muchos de los destinatarios eran personas de bajos recursos económicos que los solicitaban para cubrir necesidades urgentes y coyunturales.

La cofradía de la hermandad de San Pedro fue fundada en Pamplona en 1615 y estaba adscrita a la iglesia parroquial ${ }^{55}$. El propósito principal era promover el culto a San Pedro entre los miembros del clero y ofrecer ayuda cristiana, material, espiritual a todos los clérigos ${ }^{56}$. Los servicios que ofrecía la cofradía consistían en posada para los que viajaban a sus parroquias o por razones de trabajo, ayuda a los clérigos pobres o que se encontraban en alguna dificultad, asistencia espiritual y material en épocas de enfermedad y cuando caían en estado moribundo. También, ofrecía los servicios espirituales para los cofrades después de su muerte, pues los hermanos que le sobrevivieran debían acompañarlo en los rituales funerarios y se comprometían a pagar tres misas por las almas de los hermanos difuntos, y los que fueran sacerdotes debían decir nueve misas por los hermanos fallecidos y otra el día del aniversario de la cofradía.

Aunque en la conformación de la cofradía de San Pedro se privilegiaba la entrada de hermanos sacerdotes, también se aceptaron legos, miembros sobresalientes, casos en los cuales se les exigía suministrar información y nobleza para ser recibidos en la hermandad. A su ingreso debían dar de limosna de entrada \$200 y una libra de cera si era secular vivo, $\$ 400$ y 2 libras de cera si era secular muerto; \$16 y una libra de cera si eran clérigos y cuando estos se hallaban moribundos debían pagar $\$ 100$ y dos libras de

\footnotetext{
${ }^{54}$ Los periodos se correlacionaron directamente con el inicio de la expansión del cultivo de cacao y la crisis en la comercialización del mismo producto, lo cual significa que dicha cofradía fue un importante soporte para los cultivadores en los momentos en los que más los necesitaban.

${ }_{55}$ Archivo Arquidiocesano de Pamplona (A.A.P.), Libro 1615, pp. 41-46.

${ }^{56}$ Un estudio específico sobre la importancia y trascendencia que alcanzó la cofradía de San Pedro en el México es el de Lavrin, Asunción. "La congregación de San Pedro: una cofradía urbana del México colonial. 1604-1730”, en Historia mexicana, vol. XXIX, núm. 4, México, 1980.
} 
cera. Pero, además de las limosnas, buena parte del capital de la cofradía provenían de las donaciones que hacían sus hermanos a la hora de su muerte, pues muchos de ellos terminaron por nombrarla como única y universal heredera a su alma, entregando la totalidad de sus bienes o parte de ellos a la hermandad de San Pedro, para que los administrara y pagara con las rentas obtenidas las misas anuales, necesarias para la salvación de su alma. En tales casos la hermandad se podía desempeñar como patrón de la capellanía o algunos de sus miembros podían ser designados como capellanes. Según las órdenes expedidas por el provisor general en 1739 y 1740, los capitales de la cofradía debían ser colocados prioritariamente en censos respaldados con hipotecas seguras $^{57}$.

Como se ha señalado, la hermandad de San Pedro fue la institución cívica-religiosa con más prestigio y poder económico en la ciudad de Pamplona, durante el siglo XVIII ${ }^{58}$, pues recibió y administró directamente diferentes bienes recibidos en donación por sus miembros cofrades y como patrona de varias capellanías; entre ellas la hacienda de Matarredonda, localizada en la jurisdicción de la ciudad de Girón, la cual decidió darla en arrendamiento, y la hacienda de Agua Sucia en el valle de Cúcuta, que administró directamente. En diferentes ocasiones compró algunos bienes localizados tanto en el sector rural como urbano y algunos esclavos. Así por ejemplo, en 1729 adquirió una casa en \$400; en 1781 le compró al clérigo Juan Ignacio Gutiérrez una casa en $\$ 1.400^{59}$; y en 1783 compró otra casa que estaba situada en la calle Real ${ }^{60}$; en 1756 hipotecó parcialmente la hacienda el Corral que había comprado en el mismo año, en 1758 le compró a Antonio de la Peña una hacienda con 1.4000 árboles de cacao y dos esclavos, reconociéndole un censo a su favor ${ }^{61}$ por $\$ 1.400$; en cuanto a los esclavos, solamente compró dos y vendió cinco. Obviamente también vendía el cacao que se producía en la hacienda de Agua Sucia, Francisco Díaz de Mendoza, le compró, por ejemplo, 100 cargas de cacao. Como expresión de su benevolencia, Felipe Ramírez, presbítero, mayordomo de la Santa Hermandad de San Pedro, manumitió un mulatico; y en 1785 se le otorgó carta de libertad a una esclava que ya había entregado la suma de dinero por la cual estaba avaluada.

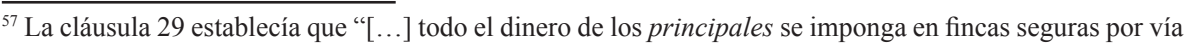
de censos"; la 30 que los principales no se podían gastar en cosa alguna; la 50 que no se podían perdonar los intereses a los censatarios "[...] por los efectos con que se mantienen los gastos de la hermandad"; la 52 que no se admitieran traspasos de censos de unas a otras personas, "[...] sino que toda redención se haga con exhibición del dinero en esta hermandad para que la imponga según las constituciones”, cláusula esta que pocas veces se cumplió. Ferreira Esparza, Carmen Adriana, Op. cit., pp. 113-114.

${ }^{58} \mathrm{Su}$ importancia era tal que para 1774, cuando se debatía las contribuciones que debían aportar las ciudades y villas para reunir la cantidad de dinero que demandaba la realización de una entrada para someter y controlar a los indios motilones, se consideró que la hermandad debía aportar $\$ 500$ al igual que el convento de Santa Clara, mientras que las ciudades de Trujillo y Pamplona debían aportar \$2.000 cada una, pues la pacificación de los indios beneficiaba a todos por igual. Es decir que la hermandad de San Pedro ya se incluía como una institución independiente que a nivel de riqueza podía estar a la altura del Convento de Santa Clara o aún de las ciudades. Archivo General de la Nación (AGN), Colonia, Caciques e Indios, Rollo 63, 328v-330r, 363r-364v.

${ }^{59}$ Archivo Notarial de Pamplona (ANP), t. 123, 59r-60v, 1783-IV.

${ }^{60}$ ANP, t. 83, 113r-114v; ANP, T123, 59r-60v.

${ }^{61}$ ANP, t. 101, 145r-146.
} 
Pero dada su naturaleza para ofrecer créditos, fue en este aspecto en el cual tuvo un mayor desempeño la cofradía de la Hermandad de San Pedro, pues los prestamistas debían hipotecar los bienes como carta de garantía de los principales que entregaba, lo que le permitía a la cofradía ampliar su radio de acción y estrechar relaciones sociales de todo tipo. Para ilustración se referencian en forma específica algunos de los 438 préstamos que realizó esta cofradía a lo largo del siglo XVIII. En 1705 la viuda María Llanos Cifuentes hipotecó 300 reses, una estancia con su casa y corral y dos esclavos para garantizar un censo que había tomado su hijo, ya fallecido, por $\$ 100^{62}$; en 1711 Nicolás Carlos Garnica Orozco reconoció un censo por $\$ 300$ que estaba cargados sobre "una casa alta, de paredes, madera y teja, situada en la plaza, con su solar cercado" ${ }^{63}$, la cual había comprado en remate por la misma cantidad del censo $^{64}$; en 1718 Salvador Ortiz Manosalba hizo un préstamo por $\$ 300^{65}$, cargando la hacienda del Pescadero, con 350 reses de ganado; en 1722 el cura Lorenzo Orozco de Acevedo le hipotecó una estancia y 50 reses, localizadas en Chima, por $\$ 500^{66}$; en 1721 Joseph Vela Patiño, alcalde mayor del real de minas de Vetas, reconoció $\$ 800$ por un censo que estaba cargado sobre unos bienes que compró (1,5 estancias, el ganado -reses, yeguas y ovejas-, los entables o cultivos, las casas y demás anexos en $\$ 4.040^{67}$ ); en 1754 Joseph Villamizar tomó un prestamos de $\$ 8.000$ y los cargó sobre la hacienda de Agua Sucia ${ }^{68}$; en 1768 Vicente Carvajal hipotecó la hacienda De García, en el valle de Cúcuta, por \$150; en 1776 Francisco Ladrón de Guevara, alcalde ordinario, reconoció un censo que pesaba sobre la hacienda El Corral de Piedra para formalizar la adquisición de esta hacienda. Sus mayordomos también realizaron préstamos, aceptando bienes que se encontraban en jurisdicción de otras ciudades, a pesar de que ello estaba tácitamente prohibido en las constituciones de la cofradía por las dificultades que se presentaban para hacer cumplir las garantías y cobrar los réditos; en 1722 Bernardo Navarro hipotecó ocho estancias con cacao y esclavos en el sitio de los Yariguíes (Girón), para respaldar un censo de \$400; en 1732 le prestó \$260 a Francisco Bustamante que hipotecó una estancia de cacao en Rionegro y una estancia de ganado mayor en Suratá, con reses, huertas y mulas ${ }^{69}$; en 1777 le prestó \$100 a Francisco Álvarez Ramírez, recibiéndole como garantía una arboleda de cacao ubicada en Barinas (Venezuela) ${ }^{70}$.

Además, administraba algunas propiedades que soportaban la fundación de capellanías y en las cuales la cofradía de la hermandad de San Pedro se desempeñaba como patrona, tal era el caso de la hacienda de Mataredonda, en Girón, sobre la cual

\footnotetext{
${ }^{62}$ ANP, t. 71, 145v-148r.

${ }^{63}$ ANP, t. 74,136r-13v.

${ }^{64}$ Ibid.

${ }^{65}$ Esta hacienda ya estaba gravada con un censo por valor de $\$ 1.100$ a favor del convento de Santa Clara (ANP, t. 78: 73v-76r).

${ }^{66}$ ANP, t. 80: 92v-95r; t. 82, 136r; t. 83, 151r-155v.

${ }^{67}$ ANP, t. 79: 164r-165v.

${ }^{68}$ ANP, Rollos; 1524134, 1523135 y 1523136.

${ }^{69}$ ANP, t. 80, 30-35, 206v-212v, t. 86, 1-5v.

${ }^{70}$ ANP, t. 118, 210v-214r.
} 
su propietaria Leonor Cortez había había fundado una capellanía el 17 de febrero de 1670 , con un principal de $\$ 3.600^{71}$; también lo era de los bienes de Juan de Areau que había fundado una capellanía con $\$ 200$ de principal; de la capellanía fundada -desde el 20 de mayo de 1718- por Juan de Figueroa con \$2.000 de principal; y de la hacienda de San Pablo, desde 1758, cuando Francisco Guerrero, natural del puerto de Santamaría del arzobispado de Sevilla y vecino de Pamplona, decidió fundar una capellanía con $\$ 10.000$ de principal $^{72}$. La hermandad también fue postulada como patrona en varias capellanías, cargo que debía asumir una vez los patrones principales y sus descendientes fallecieran; y en algunos casos las capellanías dejaban abierta la posibilidad para que además de administrar los principales ${ }^{73}$ se designaran como capellán interino algunos de los hermanos de la cofradía, tal era el caso de capellanía de Nicolás Buitrago Salazar, fundada con $\$ 1.000^{74}$.

En cuanto se refiere a los receptores de crédito, más que a las personas que en su mayoría eran vecinos dedicados a las actividades agrícola-ganaderas, propietarios de bienes urbanos, algunos comerciantes y miembros del sector religioso; se consideró importante tratar de establecer los centros receptores de los créditos, pues ellos tenían una mayor diferenciación en términos de factores geográfico-climatológicos, expansión de la frontera agrícola y comercial, vocación productiva y relaciones comerciales establecidas con centros de consumo o distribución de los principales productos de la región, tales como cacao, derivados de la ganadería y la caña de azúcar y las harina; así como de la procedencia de las importaciones de bienes especialmente de España o de otras colonias americanas. Estas dinámicas fortalecieron tanto el poblamiento urbano como el de la expansión de la frontera agrícola, y generó polos de atracción que, a su vez, dieron origen a una marcada distribución espacial que configuró el territorio pamplonés en dos espacios claramente diferenciados: el primero correspondió a la denominada Zona Andina, en la que la frontera agrícola y agro- minera avanzó sobre la cordillera; el segundo se denominó como la Zona Valle, y en la que la frontera agro-ganadera dominó los valles y las cuencas de los ríos de la provincia. Así entonces se pudo determinar que del total de los censos otorgados

\footnotetext{
${ }^{71}$ Inicialmente, la hacienda había sido dejada al Colegio de la Compañía de Jesús con el gravamen de pagar esta capellanía y si esta no aceptaba tal encargo, como efectivamente sucedió; la hacienda debía ser entregada a la Hermandad de San Pedro.

${ }^{72}$ ANP, Rollos 1524134, 1523135 y 1523136.

${ }^{73} \mathrm{La}$ administración de los bienes de las capellanías implicaban algunos riesgos que iban desde los atrasos en los pagos de los réditos, el deterioro paulatino de los bienes, hasta la pérdida total. Algunos casos que se presentaron fueron el de Esteban de la Fuente, a quien la hermandad le había prestado $\$ 100$, desde el 10 de julio de 1726, y para respaldarla había hipotecado dos estancias de pan con 1.000 árboles de cacao que tenía en la jurisdicción de la ciudad de Salazar; y otra media estancia con 50 reses que tenía en la jurisdicción de la ciudad de Pamplona; pero no había pagado un solo peso de réditos; el de don Andrés Rojas que le debía \$200 a la hermandad de San Pedro y sus bienes, unas tierras dadas en hipoteca, fueron rematadas pero no hubo postor alguno. Rojas murió en suma pobreza; de otro lado, parte de los bienes de la capellanía de Leonor Cortez, -unas casas que servían de residencia al Capellán- se vinieron a ruina; por lo que la Hermandad tuvo que comprar otras casas, el 2 de julio de 1729, en el remate de los bienes del gobernador Pedro Varela, por \$400, endeudándose con la capellanía de Pedro de Andrade y Brito.

${ }^{74}$ Además el principal podía ser tomado por el capellán como sucedió con esta capellanía, pues el 25 de enero de 1708 se le prestó $\$ 300$ al capellán designado por Don Nicolás, Ignacio Buitrago, quien ya había recibido las órdenes sacerdotales.
} 
a lo largo del siglo XVIII, en la Zona Andina se efectuaron 1.588 operaciones de crédito (46,8\% del total) por un valor de $\$ 621.793(32,4 \%)$, mientras que en la zona del valle se realizaron 1.804 transacciones (53,2\%) por un valor de $\$ 1$ '299.341, que representaron el 67,6 \% del total, es decir más del doble de lo transado en la parte andina. En total, en las 3.392 operaciones de censo que se efectuaron en la provincia de Pamplona, se distribuyeron \$1'921.140 entre dieciséis poblaciones del área andina ${ }^{75}$ y trece de la zona del Valle ${ }^{76}$, con un promedio de $\$ 566,4$ por censo. Los censos otorgados a partir de la cofradía siguieron parámetros similares, aunque con una mayor incidencia en los cascos urbanos, donde el utillaje material de las ciudades y los cargos públicos fueron utilizados para soportar los bienes hipotecados dados en respaldo de los censos recibidos.

\section{A manera de conclusión}

A pesar de la importancia que tuvo el crédito en el desenvolvimiento de la economía colonial, esta es una de las variables que poco ha llamado la atención de los historiadores en el caso del Nuevo Reino de Granada, y no solo el referido al crédito eclesiástico, sino también el que provenía del sector público de la Real Hacienda y de los particulares en el conjunto de las relaciones comerciales que establecían entre sí. En lo que hace referencia al crédito eclesiástico, este déficit de estudios hace que aún permanezcan en el imaginario historiográfico hipótesis tradicionales sobre el rol de la Iglesia como institución monopólica de los excedentes de acumulación que generaban las actividades productivas, el efecto negativo de las actividades crediticias sobre la dinámica del desarrollo económico, la estrecha relación simbiótica entre la Iglesia y las élites de poder, etc., cuando todas estas hipótesis han sido revaluadas y renovadas y actualmente se exige estudiar más que la Iglesia como un todo, analizar en forma específica a las distintas instituciones y corporaciones que las conformaban; igualmente el análisis comparativo con las otras fuentes de crédito ha permitido constatar cómo los mecanismos que utilizó el eclesiástico permitió dinamizar el crecimiento económico colonial en la medida en brindó oportunidades de inversión, democratizó su acceso a grupos amplios de la población y facilitó el acceso y movilidad de la propiedad territorial, entre otros aspectos de carácter económico.

La dificultad para el estudio del crédito eclesiástico, para el caso granadino, puede derivarse de la escasez de fuentes oficiales de carácter agregado, o de la dificultad

\footnotetext{
${ }^{75}$ La zona andina estaba subdividida, a su vez, en dos partes, una de influencia agro-minera y la otra agrícola de subsistencia. La primera estaba compuesta principalmente por las poblaciones de Pamplona, Silos, Labateca, Suratá, Cácota de Velasco, Matanza, Tona, Vetas y un poco más distante, el distrito minero de Bucaramanga. La zona agrícola de subsistencia, estaba formada por los centros poblados de Málaga, Cerrito, Concepción, Guaca, Servitá y Tequia, ubicados al occidente de la ciudad de Pamplona, sobre la cordillera oriental.

${ }^{76}$ Esta zona se subdividió en dos subzonas: la del valle, propiamente dicho, conformado por las poblaciones de San José de Cúcuta, Rosario de Cúcuta, San Faustino, San Cayetano, Táchira y San Antonio, y la del piedemonte, integrada por Salazar, Bochalema, Chinácota, Chopo, Arboledas, San Cristóbal y Santiago. En la primera zubzona se presentó un proceso de consolidación del poblamiento, tanto indígena, al agregarse al pueblo de indios de Cúcuta los pueblos de Chinácota, Arboledas y Chopo, ordenado por Francisco Antonio Moreno y Escandón en 1778, como español al elevarse de rango a las parroquias de Nuestra Señora del Rosario de Cúcuta y San Joseph de Cúcuta, y convertirlas en villas en 1792 y 1793, lo que les daba plena autonomía político-administrativa y el derecho a tener autoridades propias con la institución del cabildo.
} 
para acceder a los archivos de instituciones religiosas, por lo que necesariamente habría que realizar un dispendioso trabajo en los archivos notariales en los cuales reposan las escrituras respectivas; pero si se desea avanzar en la comprensión de las economías y las sociedades regionales, sobre todo de aquellas que tenían eminentemente una vocación agropecuaria, es necesario realizar este esfuerzo, pues a partir de esta fuente documental y su tratamiento sistemático se puede reconstruir las características de los que prestaban y pidieron créditos, así como las relaciones entre los diferentes sectores involucrados (Iglesia, élite, pequeños productores de cacao, comerciantes, etc.), los montos, el origen de la deuda, es decir si se trataba de un censo, un depósito irregular, u otro mecanismo crediticio, los bienes hipotecados, en caso de que los hubieran, y aún, en algunas ocasiones, el destino del capital prestado. Evidentemente, este tipo de estudios contribuirían no solo a dinamizar las investigaciones de la historia económica a escala regional, sino a enriquecerla desde otras perspectivas y miradas como la social, la cultural, de las mentalidades, de la historia institucional, la ideológica y la política.

Este artículo destaca la importancia de considerar en forma particular una de las diferentes instituciones de la Iglesia, las cofradías, y muestra cómo para el siglo XVIII habían superado las tradicionales limitaciones económicas a que estaban sujetas en función de la percepción de sus ingresos a partir de las cuotas y limosnas de los hermanos cofrades, y el enfoque de ser simplemente instituciones que cumplían funciones asistenciales y de piedad y caridad, para desempeñarse como una institución económica que se habían fortalecido como resultado de la diversificación de las formas de acumulación de capital, las estrategias desplegadas para diversificar sus inversiones con el objeto de aumentar sus bienes y rentas, cuya importancia dependía de la magnitud del capital líquido puesto en movimiento. El éxito en este tipo de actividades se revertía socialmente en su capacidad de aglutinar a un mayor número de miembros y en la fastuosidad con las cuales podían celebrar las fiestas religiosas de sus santos patrones y atender las demandas espirituales y materiales de sus hermanos cofrades.

\section{Bibliografía}

\section{Fuentes primarias}

\section{Archivo}

Archivo Notarial de Pamplona (ANP), ts. 70-138; Rollos 1524134, 1524135, 1524136.

Archivo Notal de Cúcuta (ANC), ts. 1-12.

Archivo Arquidiocesano de Pamplona AAP).

Archivo General de la Nación (AGN), Colonia, Capellanías, Censos, Conventos, Caciques e Indios. 


\section{Fuentes secundarias}

\section{Libros}

Álvarez Santalo, Carlos, et al. La religiosidad popular. Barcelona: Anthropos, 1989.

Aries, Philippe. El hombre ante la muerte. Madrid: Taurus, 1983.

Bauer, Arnold. La iglesia en la economía de América Latina siglos XVI al XIX. México: Instituto Nacional de Antropología e Historia, 1986.

Bazarte Martínez, Alicia. Las cofradías de españoles en la ciudad de México (15261869). México: Universidad Autónoma de México, 1989.

Bechtoloff, Damar. Las cofradías en Michoacán durante la época de la colonia. México: Colegio de Michoacán-Colegio Mexiquense, 1996.

Celestino, Olinda y Meyers, Albert. Cofradias en el Perú: Región central. Frankfurt: Vervuert, 1981.

Chamoux, Marie-Nöelle, et al., (coords.). Prestar y pedir prestado. Relaciones sociales y crédito en México del siglo XVI al XIX, México: Secretaría de Educación Pública/ Centro de Investigaciones y Estudios Superiores en Antropología Social, 1993.

Colmenares, Germán. Cali: Terratenientes, mineros y comerciantes, Siglo XVIII. Bogotá: Banco Popular, 1983.

Egoavil, Teresa. Las Cofradias en Lima, siglos XVII y XVIII. Lima: Universidad Nacional Mayor San Marcos, 1986.

Eliade, Mircea. Lo sagrado y lo profano. Barcelona: Labor, 1983.

Ferreira Esparza, Carmen Adriana. La economía espiritual. Entre lo terrenal y lo celestial. Pamplona: Siglo XVIII, 2001.

González Acero, Juan Francisco. La cofradía de las Benditas Ánimas del Purgatorio en Fontibón 1683-1693. Bogotá: Pontificia Universidad Javeriana, 2013.

Le Goff, Jacques. El nacimiento del Purgatorio. Madrid: Taurus, 1981.

Le Goff, Jacques. La bolsa y la vida. Economía y religión en la edad media. Barcelona: Gedisa, 1987.

Lomnitz, Claudio. La idea de la muerte en México. México: Fondo de Cultura Económica, 2006. 
López Muñoz, Miguel. Las cofradías de la parroquia de Santa María de la Magdalena de Granada en los siglos XVII y XVIII. Granada: Universidad de Granada, 1992.

Luque Alcaide, Elisa. La cofradía de Aranzazu de México (1681-1799). Pamplona: Eunate, 1995.

Martínez López-Cano, Pilar (comp.). Iglesia, estado y economía. Siglos XVI al XIX. México: Instituto de Investigaciones Históricas Dr. José María Luis Mora, 1995.

Martínez López-Cano, Pilar; Von Wobeser, Gisela y Muñoz, Juan Guillermo (coords.). Cofradias, capellanias y obras pías en la América Colonial. México: Universidad Nacional Autónoma de México, Instituto de Investigaciones históricas, 1998.

Marulanda Restrepo, Juan Sebastián. Comprando la eternidad a veinte mil el millar. El crédito religioso en la provincia de Antioquia, 1675-1750. Medellín: Instituto para el desarrollo de Antioquia, 2013.

Rico Villamizar, José. Pamplona o la historia del nororiente colombiano. Bogotá: Crea Arte, 1990.

Rodríguez González, Ana Luz. Cofradías, capellanías, epidemias y funerales. Una mirada al tejido social de la Independencia. Bogotá: Banco de la República, 1999.

Schumpeter, Joseph. Historia del Análisis Económico. Barcelona: Ariel, 1971.

Sotomayor, María Lucía. Cofradías, caciques y mayordomos. Reconstrucción social y reorganización política en los pueblos de indios, siglo XVIII. Bogotá: Instituto Colombiano de Antropología e Historia, 2004.

Von Wobeser, Gisela. El crédito eclesiástico en la Nueva España. Siglo XVIII. México: Universidad Nacional Autónoma de México, Coordinación de Humanidades e Instituto de Investigaciones Históricas, 1994.

Von Wobeser, Gisela. Vida eterna y preocupaciones terrenales. Las capellanías de misas en la Nueva. España, 1600-1821. México: Universidad Nacional Autónoma de México, 2005.

\section{Capítulos de libros}

Callahan, William J. "Las cofradías y hermandades de España y su papel social y religioso dentro de una sociedad de estamentos", en Martínez López-Cano, Pilar; Von Wobeser, Gisela y Muñoz, Juan Guillermo (coords.), Cofradias, capellanías y obras pías en la América Colonial. México: Universidad Nacional Autónoma de México, Instituto de Investigaciones históricas, 1998.

Cervantes Bello, Francisco J. "La ciudad en la organización del crédito regional: Puebla a principios del siglo XVII", en Cervantes Bello, Francisco Javier (coord.), Las dimensiones sociales del espacio en la historia de Puebla, siglos XVII-XIX. México: Benemérita Universidad Autónoma de Puebla, 2001. 
Lavrin, Asunción. "Cofradías novohispanas: economías material y espiritual”, en Martínez López-Cano, Pilar; Von Wobeser, Gisela y Muñoz, Juan Guillermo (coords.), Cofradías, capellanías y obras pías en la América Colonial. México: UNAM, 1998.

Lavrin, Asunción. "Los conventos de monjas en la Nueva España", en Bauer, Arnold J., La iglesia en la economía de América Latina siglos XVI al XIX. México: Instituto Nacional de Antropología e Historia, 1986.

Lavrin, Asunción. "Mundos en contraste: cofradías rurales y urbanas en México a fines del siglo XVIII", en Bauer, Arnold J., La iglesia en la economía de América Latina. México: Instituto Nacional de Antropología e Historia, 1986.

Martínez López-Cano, Pilar. "Balance de los estudios sobre el crédito colonial", en Guedea, Virginia y Ludlow, Leonor (coords.), El historiador frente a la historia. Historia económica en México. México: Universidad Nacional Autónoma de México, Instituto de Investigaciones Históricas, 2003.

Martínez López-Cano, María del Pilar. "La Iglesia y el crédito en Nueva España: entre viejos presupuestos y nuevos retos de investigación”, en Martínez López-Cano, María del Pilar (coord.), La Iglesia en Nueva España. Problemas y perspectivas de investigación. México: Universidad Nacional Autónoma de México, Instituto de Investigaciones Históricas, 2010.

Martínez de Codes, Rosa María. "Cofradías y capellanías en el pensamiento ilustrado de la administración borbónica (1760-1808)”, en Martínez López-Cano, Pilar; Von Wobeser, Gisela y Muñoz, Juan Guillermo (coords.), Cofradias, capellanías y obras pías en la América Colonial. México: Universidad Nacional Autónoma de México, Instituto de Investigaciones históricas, 1998.

Reyes Escalera, Javier. "Hermandades, religión oficial y poder en Andalucía", en Álvarez Sábato, Carlos; Buxo I Rey, María Jesús y Rodríguez Bonera, Salvador (coords.), La religiosidad popular. Hermandades, romerías y santuarios. Barcelona: Anthropos, 1989.

\section{Artículos de revistas}

Carbajal López, David. "La reforma de las cofradías en el siglo XVIII: Nueva España y Sevilla en comparación", en Revista Complutense de Historia de América, vol. XXXVIII, 2012.

Celestino, Olinda y Meyers, Albert. "La dinámica socio-económica del patrimonio cofradial en el Perú colonial: Jauja en el siglo XVII", en Revista Española de Antropología Americana, vol. XI, 1981.

Colmenares, Germán. “Censos y capellanías. Formas de crédito en una economía agrícola”, en Cuadernos Colombianos, núm. 2, Bogotá, 1974. 
Chance, John y Taylor, William. "Cofradías y cargos: una perspectiva histórica de la jerarquía cívico religiosa mesoamericana”, en Antropología (suplemento). Boletín Instituto Nacional de Antropología e Historia, núm. 14, 1987.

Díaz A., Alberto; Martínez S., Paula y Ponce, Carolina. "Cofradías de Arica y Tarapacá en los siglos XVIII y XIX. Indígenas andinos, sistema de cargos religiosos y festividades", en Revista de Indias, vol. LXXIV, núm. 260, 2014.

Esteras, Cristina y Gutiérrez Cedodal, Ramón. "La cofradía de San Eloy de los plateros de Lima”, en Revista de Historia del Arte, Atrio, vol. X, núm. 11, 2005.

Ferreira Esparza, Carmen Adriana. "El crédito colonial en la provincia de Pamplona-Nueva Granada: usos del censo consignativo", en Signos Históricos, núm. 1, 1999.

Ferreira Esparza, Carmen Adriana. "Nuestra Señora de las Angustias del pueblo de indios de Labateca. La doble cara de la cofradía colonial", en Anuario de Historia Regional y de las Fronteras, núm. 6, Bucaramanga, Universidad Industrial de Santander, 2002.

García Ayluardo, Clara. "Sociedad, crédito y cofradía en la Nueva España a fines de la época colonial: el caso de Nuestra Señora de Aránzazu”, en Historias, núm. 3, 1983.

Lavrin, Asunción. "La riqueza de los conventos de monjas en Nueva España. Estructura y evolución durante el siglo XVIII", en Cahiers des Ameriques Latines, vol. VIII, 1973.

Lavrin, Asunción. "La congregación de San Pedro: una cofradía urbana del México colonial. 1604-1730”, en Historia mexicana, vol. XXIX, núm. 4, 1980.

Lavrin, Asunción. "El capital eclesiástico y las élites en Nueva España”, en Mexican Studies/Estudios Mexicanos, vol. I, núm. 1, 1985.

Macleod, Murdo. "Papel social y económico de las cofradías indígenas de la colonia en Chiapas", en Mesoamérica, núm. 5, 1983.

Matos Hurtado, Belisario. "Apuntaciones y documentos para la historia de Pamplona: La Cofradía de la Santa Veracruz y el Santo Crucifijo del Humilladero", en Boletín de Historia y Antigüedades, vol. XXXI, núm. 39, 1944.

Pérez-Rocha, Emma, "Mayordomías y cofradías del pueblo de Tacuba en el siglo XVIII", en Estudios de Historia Novohispana, vol. VI, Universidad Nacional Autónoma de México, Instituto de Investigaciones Históricas, México, 1978. 
Sotomayor, María Lucía. "Organización socio-política de las cofradías”, en Revista Colombiana de Antropología, vol. XXIX, 1992.

Tovar Pinzón, Hermes. "El cacao en la sociedad colonial llegó a ser el primer producto agrario de exportación”, en Revista Credencial Historia, núm. 130, 2000.

Von Wobeser, Gisela, "La postura de la iglesia católica frente a la usura", en Memorias de la Academia Mexicana de la Historia, vol. XXXVI, 1993.

\section{Tesis}

Guerrero Rincón, Amado Antonio, Territorio, Economía y Sociedad. Desarrollo Regional en la provincia de Pamplona, siglo XVIII, (tesis doctoral), Universidad Internacional de Andalucía, 2014.

Wendell Graff, Gary. Cofradias in the New Kingdom of Granada: lay fratiernities in a spanish american frontier saciety. 1600-1755, (tesis doctoral), University Microfilms international, Universidad de Wisconsin, 1973.

\section{Publicaciones en Internet}

Cruz Rangel, José Antonio. "Las cofradías indígenas en el siglo XVIII, un sistema colonial de poder, resistencia, y exacción. El caso de Chimalhualcan, Atenco", en Dimensión Antropológica, http://www.dimensionantropologica.inah.gob. $\mathrm{mx} / \mathrm{p}=1050$.

Martínez Domínguez, Héctor. Las Cofradías en La Nueva España, http://cdigital. uv.mx/bitstream/123456789/7975/2/anua-Ipag45-71.pdf. 